OPEN ACCESS

Edited by:

Francisco Jose Barba, University of Valencia, Spain

Reviewed by:

Maria Lavilla,

Technological Center Expert in Marine and Food Innovation (AZTI), Spain Humberto Vega,

Celgene, United States

*Correspondence:

Robert Sevenich

r.sevenich@tu-berlin.de

tThese authors have contributed equally to this work

Specialty section: This article was submitted to

Nutrition and Food Science Technology,

a section of the journal

Frontiers in Nutrition

Received: 18 December 2020 Accepted: 08 February 2021

Published: 18 March 2021

Citation:

Gratz M, Sevenich R, Hoppe T, Schottroff F, Vlaskovic N, Belkova B, Chytilova L, Filatova M, Stupak M Hajslova J, Rauh $C$ and Jaeger $H$

(2021) Gentle Sterilization of

Carrot-Based Purees by High-Pressure Thermal Sterilization and Ohmic Heating and Influence on Food Processing Contaminants and Quality Attributes.

Front. Nutr. 8:643837. doi: 10.3389/fnut.2021.643837

\section{Gentle Sterilization of Carrot-Based Purees by High-Pressure Thermal Sterilization and Ohmic Heating and Influence on Food Processing Contaminants and Quality Attributes}

\author{
Maximilian Gratz ${ }^{1 \dagger}$, Robert Sevenich ${ }^{2,3 * t}$, Thomas Hoppe ${ }^{2}$, Felix Schottroff ${ }^{1,4}$, \\ Nevena Vlaskovic ${ }^{1}$, Beverly Belkova ${ }^{5}$, Lucie Chytilova ${ }^{5}$, Maria Filatova ${ }^{5}$, Michal Stupak ${ }^{5}$, \\ Jana Hajslova ${ }^{5}$, Cornelia Rauh ${ }^{2}$ and Henry Jaeger ${ }^{1}$ \\ ${ }^{1}$ Institute of Food Technology, University of Natural Resources and Life Sciences (BOKU), Vienna, Austria, ${ }^{2}$ Department of \\ Food Biotechnology and Food Process Engineering, Technische Universität Berlin (TU Berlin), Berlin, Germany, ${ }^{3}$ Leibniz \\ Institute for Agriculture Engineering and Bioeconomy (ATB) Potsdam, Berlin, Germany, ${ }^{4}$ Core Facility Food \& Bio Processing, \\ University of Natural Resources and Life Sciences, Vienna, Austria, ${ }^{5}$ Department of Food Analysis and Nutrition, University of \\ Chemistry and Technology (VSCHT), Prague, Czechia
}

Pressure-enhanced sterilization (PES) and ohmic heating $(\mathrm{OH})$ are two emerging sterilization techniques, currently lacking implementation in the food industry. However, both technologies offer significant benefits in terms of spore inactivation using reduced thermal intensity in food products, as well as minimized effects on sensory and nutritional profiles. In this study, PES and $\mathrm{OH}$ were tested based on possible food safety process windows in comparison to thermal retorting, to optimize the food quality of carrot-based purees. The following parameters related to food quality were tested: texture, carotenoid content, color, and detectable amount of food processing contaminants (FPC) formed. Application of the innovative sterilization techniques resulted in a better retention of color, texture, and carotenoids (for PES) as well as a reduced formation of food processing contaminants. Importantly, a significant reduction in the formation of furan and its derivates was observed, compared to the retorted samples. Hence, both sterilization technologies showed promising results in the mitigation of potential toxic processing contaminants and retention of quality attributes.

Keywords: sterilization, high-pressure thermal sterilization, ohmic heating, food processing contaminants, physicochemical properties

\section{INTRODUCTION}

Consumers increasingly demand high-quality foods with a longer shelf life and optimized nutritional attributes. The process currently used in the food industry to achieve a sterile product for low-acid foods is retorting, where applied temperature time profiles can have a negative impact on the nutritional value of the foods (1). Moreover, the formation of processing contaminants, i.e., chemical substances with potentially harmful effects on consumer health, is promoted during severe heat treatments and becomes more and more a subject of scientific and industrial interest $(2,3)$. 
Therefore, novel preservation technologies capable of reducing the thermal process intensity may help to overcome this issue, simultaneously resulting in products with improved sensorial properties with a comparable shelf life yielding a more attractive visual appearance and a better, fresher taste. Among the most promising emerging technologies for the gentle sterilization of foods are, first, high hydrostatic pressure in combination with elevated temperatures, and second, ohmic heating $(\mathrm{OH})$.

For sterilization applications, high pressure $(\geq 600 \mathrm{MPa})$ can be used in combination with elevated temperatures (90$121^{\circ} \mathrm{C}$ ), as a combined process to inactivate spores (4-9) - the so-called high-pressure thermal sterilization (HPTS) $(1,10,11)$. Within HPTS, there are currently two processes that have been accepted by the US Food and Drug Administration (FDA): First is the pressure-assisted thermal sterilization (PATS) (12). Here, pressure $\geq 600 \mathrm{MPa}$ is used for rapid heating purposes only, the synergistic effect of $\mathrm{p}, \mathrm{T}$ is neglected, only equivalent treatment conditions to thermal retorting are valid, and the PATS process is listed as a thermal process. Second, in 2015, pressure-enhanced sterilization (PES) was accepted by the FDA, where temperatures below $121.1^{\circ} \mathrm{C}$ at $600 \mathrm{MPa}$ can be applied (13). Here, the synergistic effect of pressure and temperature on spore inactivation was accounted for after intensive research and mechanistic studies to understand the impact of $\mathrm{p}, \mathrm{T}$ on spores. PES is a possible process window within the pressure ( $>600$ $\mathrm{MPa})$, temperature $\left(110-120^{\circ} \mathrm{C}\right)$, and time (1-10 min) domain of HPTS.

The temperature for sterilization can be reached by adiabatic heat of compression when starting temperatures between 70 and $90^{\circ} \mathrm{C}$ are chosen. Depending on the food system, this temperature increase can range from 3 to $9^{\circ} \mathrm{C}$ per $100 \mathrm{MPa}$ and represents a rapid volumetric heating that further helps to reduce unwanted thermal effects compared to the effects of conventional heat transfer. The reduction in the thermal effects is due to the synergistic effect of pressure and temperature on the spore inactivation as well as the fact that some thermally driven reactions cannot occur under pressure $(1,14,15)$. PES is a promising technology, which has not yet been implemented in the food industry. PES could eventually replace conventional thermal sterilization, producing high-quality, shelf-stable, lowacid foods at lower processing temperatures.

Ohmic heating, on the other hand, is an industrial alternative to traditional heating processes (16-18). For this treatment, alternating current $(\mathrm{AC})$ is directly applied to the food, and heat is generated due to the electrical resistance of the product. In comparison to conventional heating technologies, $\mathrm{OH}$ bears the advantages of a volumetric process, i.e., avoiding heat transfer through hot surfaces (19). Additionally, rapid heating at relatively low-temperature gradients inside the product can be achieved if an appropriate configuration of the treatment chamber is chosen. Thus, heating time can be significantly shortened, resulting in a reduced thermal impact and an associated decrease in negative alterations of the product quality at an equivalent sterilization effect compared to conventional thermal processes $(20,21)$.

Furthermore, PES and $\mathrm{OH}$ seemed to have a positive impact on a lower formation of food processing contaminants in food systems, e.g., furan (classified as a potential human carcinogen, 2B) (22), compared to conventional retort sterilization. Baby food formulae are of particular interest in this context, as the presence of processing contaminants in these foods was considered a health concern for toddlers and infants (3). For PES, shorter processing times, Le Chatelier's principle, and lower process temperatures due to additional non-thermal effects may contribute to this phenomenon (23-27). In terms of $\mathrm{OH}$, the volumetric current flow through the product enables the implementation of very rapid heating, leading to improved hightemperature short-time processes with reduced cooking damage ( $C$ value) but maintained sterilization value $\mathrm{F}_{0}$ (28). Thus, recently, $\mathrm{OH}$ was successfully applied to reduce the formation of food processing contaminants during sterilization of vegetable baby food formulations $(29,30)$.

The mitigation of food processing contaminants, especially furan and acrylamide, is a crucial issue that must be solved by the food industry in the near future because future guidelines will almost certainly include limits for food processing contaminants (FPCs) in foods. Therefore, the aim of this study was to comprehensively assess the benefits of the new processing technologies $\mathrm{PES}$ and $\mathrm{OH}$, compared to conventional retort sterilization, considering the effects on product quality and to enable the analytical identification of product quality markers.

\section{MATERIALS AND METHODS}

In this study, two different volumetric inactivation technologies, i.e., PES and $\mathrm{OH}$, were compared as to the formation of processing contaminants as well as to their influence on product quality characteristics.

\section{Sample Preparation}

Chicken rice puree (CRP) was provided by an industry partner. The recipe was feasible for baby food puree preparation and included the following ingredients: carrots, $40 \%$; water, $33.2 \%$; rice, $10 \%$; raw chicken meat, $8 \%$; turnip cabbage, $4 \%$; onion, $2 \%$, rapeseed oil, $1.5 \%$; and table salt, $0.3 \%$. All samples were taken from the same batch and obtained in a frozen state in $1-\mathrm{kg}$ plastic bags.

Reference (benchmark retorting) samples were processed by a standard industrial retort process $\left(\mathrm{F}_{0}=7 \mathrm{~min}\right)$ and then provided for analysis by the industry partner. Prior to processing, the desired amount of untreated sample was gently defrosted, and the characteristics of the batch were analyzed. Typical values for the $\mathrm{CRP}$ were $\mathrm{pH}=6.47 \pm 0.1$, electrical conductivity $=7.35 \pm 0.24$ $\mathrm{ms} / \mathrm{cm}$, water activity $=0.974 \pm 0.04,{ }^{\circ}$ Brix $=3.75 \pm 0.35^{\circ}$, and color values $\mathrm{L}^{*}=65.8 \pm 0.8, \mathrm{a}^{*}=30.6 \pm 2.2$, and $\mathrm{b}^{*}=60.3 \pm 1.6$.

Furthermore, to validate and test the analytical method for furan and its derivatives determination [solid-phase microextraction (SPME) gas chromatography-high-resolution mass spectrometry (GC-HRMS) analysis, see Analysis of Food Processing Contaminants], two model food systems consisting of carrots, oil, and water (Table 1) were prepared, treated by PES (PES and Thermal References) and $\mathrm{OH}$ and retort (Thermal Sterilization by $\mathrm{OH}$ and Retort) and analyzed. 
TABLE 1 | Recipes of the model food system.

\begin{tabular}{lclc}
\hline \multicolumn{2}{c}{ Recipe puree 1 } & \multicolumn{2}{c}{ Recipe puree 2 } \\
\hline Carrots & $90 \%$ & Carrots & $90 \%$ \\
Water & $8 \%$ & Water & $8 \%$ \\
Olive oil (extra virgin) & $2 \%$ & Rapeseed oil & $2 \%$ \\
\hline
\end{tabular}

For this purpose, fresh carrots (Daucus carota subsp. sativus) were purchased at a local supermarket, peeled, and cut into 1$\mathrm{cm}$ thick slices. Carrot slices were precooked in $90^{\circ} \mathrm{C}$ tap water for $10 \mathrm{~min}$ and subsequently finely pureed (Microcut MC 12, Stephan Machinery GmbH, Hameln, Germany). Subsequently, the carrot puree was mixed with tap water, olive oil, or rapeseed oil, filled in bags, and stored at $-30^{\circ} \mathrm{C}$ until sterilization experiments. To ensure comparability for all used technologies (PES, OH, and retort), the same batch of CRP and of the carrotoil model food systems were used for the trials.

\section{Sterilization Treatments}

In this study, the effects of high-pressure thermal sterilization (PES) on product quality were compared to those of $\mathrm{OH}$ and conventional retort. As $\mathrm{OH}$ is considered a predominantly thermal technology (31), the process design was based on the previously validated (data not shown) and well-established concept of $\mathrm{F}_{0}$ values (28). It is worth noticing, that an extensive database on inactivation kinetics in a $\mathrm{p}-\mathrm{T}-\mathrm{t}$ landscape for PES is not available to date. Hence, microbial inactivation studies had to be carried out prior to the planned studies on the influence of this treatment on product quality and were used as a basis for later process design. These microbiological analyses are summarized in the Supplementary Material 1 of this paper.

For this study, all trials related to PES were carried out by research partner TU Berlin in Berlin, Germany; $\mathrm{OH}$ experiments were accomplished by BOKU in Vienna, Austria; and instrumental analysis was carried out by VSCHT in Prague, Czech Republic. Shipment of samples was carried out in a frozen state by express shipping.

\section{PES and Thermal References}

The high-pressure unit U111 (Unipress, Warsaw, Poland) was used to conduct the PES studies (Figure 1). With this unit, pressures up to $700 \mathrm{MPa}$ and temperatures up to $130^{\circ} \mathrm{C}$ can be reached. The high-pressure transmitting medium was silicone oil (M 40.165.10, Huber GmbH, Offenburg, Germany). The unit consists of five chambers, with a volume of $4 \mathrm{ml}$ each, immersed in an oil bath. The pressure build-up rate was $25 \mathrm{MPa} / \mathrm{s}$.

To monitor the temperature during the treatment, a control sample filled with puree was put in one of the chambers equipped with a thermocouple (Unipress, Warsaw, Poland) placed in the geometrical center of the sample. The temperatures selected for the treatment were between 105 and $121^{\circ} \mathrm{C}$ at $600 \mathrm{MPa}$ with treatment times from 0.166 up to $100 \mathrm{~min}$. The oil bath of the $\mathrm{U} 111$ was set to the selected process temperature plus $5^{\circ} \mathrm{C}$, and the start temperatures for the food system were obtained in pretrials (Table 2).
The trials for the analysis of food processing contaminants and quality parameters were completed in duplicates with samples of the model food purees or the CRP. Portions of the mixed matrix (1.5 g) were placed in a container (Nunc Cryo Tubes Nr. 375299, Nunc A/S, Roskilde, DK) and put into an ice bath. After the treatment, the samples were put immediately on ice to reduce further formation of processing contaminants and then frozen at $-80^{\circ} \mathrm{C}$. The carrot-oil model food system was treated at different temperatures $\left(105,110\right.$, and $\left.115^{\circ} \mathrm{C}\right)$ for $5-10 \mathrm{~min}$ with and without pressure to observe furan formation.

The thermal references were conducted in the same container $(1.5 \mathrm{~g})$ using the same $\mathrm{T}$, $\mathrm{t}$ combinations $\left(105,110\right.$, and $115^{\circ} \mathrm{C}$ for $5-10 \mathrm{~min}$ at $0.1 \mathrm{MPa}$ ) as the PES-treated samples. A thermostatic bath (cc2, Huber GmbH, Offenburg, Germany) filled with silicon oil (M40.165.10, Huber $\mathrm{GmbH}$ ) was used for the thermal reference treatment. Following thermal treatment, the samples were immediately transferred to an ice bath. The selected treatment conditions are shown in Table 3. For the CRP, the aim was to find $\mathrm{p}, \mathrm{T}, \mathrm{t}$ combinations that provided a $12 \log _{10}$ inactivation of Bacillus amyloliquefaciens to ensure a safe sterilization treatment. To find suitable process windows, inactivation trials were done as described in the Supplementary Material 1. The resulting process conditions are shown in Table 3.

In the food industry, $\mathrm{F}_{0}$ values (referring to $121^{\circ} \mathrm{C}$ reference temperature and a $\mathrm{z}$ value of $10^{\circ} \mathrm{C}$ ) between 4 and $10 \mathrm{~min}$ are commonly used for thermal sterilization treatments (32). However, a comparison with high-pressure sterilization in terms of spore inactivation is difficult because at high temperature and $600 \mathrm{MPa}$, the inactivation can be very sudden and rapid due to additional, non-thermal effects (9). Therefore, only the $C$ value concept was applicable to compare the cooking damage between retorting, $\mathrm{OH}$, and PES (see C Value Calculation).

\section{Ohmic Heating}

$\mathrm{OH}$ was performed using a pilot-scale generator (German Institute of Food Technologies, DIL, Quakenbrück, Germany). The generator applied rectangular bipolar pulses at a pulse repetition rate of $12 \mathrm{kHz}$. The system possesses a maximum power of $15 \mathrm{~kW}$ with a maximum voltage of $500 \mathrm{~V}$ (peak). By adjustment of the pulse width (between 10 and $40 \mu \mathrm{s}$ ), a constant power was applied during the treatments.

The trials were carried out using a self-built cylindrical double jacket chamber designed to provide uniform heating profiles at sterilization conditions. The body of the chamber was made of polyether ether ketone (PEEK), and the electrodes consisted of stainless steel (Figure 2). The chamber was built to allow runs at temperatures above $130^{\circ} \mathrm{C}$ and to minimize cold spots on the outside by simultaneously heating the double jacket (outer chamber) during $\mathrm{OH}$.

The inner chamber $(230 \mathrm{ml})$ for the treatment of the product was designed to geometrically and volumetrically resemble the glass jars used for retort sterilization, with a diameter of $60 \mathrm{~mm}$ and a length of $80 \mathrm{~mm}$. Together with the outer chamber, the total filling volume was $1.8 \mathrm{~L}$. For the sterilization runs, $2 \mathrm{~kW}$ power was applied. Purees were filled into the chamber at room temperature and heated by the application of the electric field 


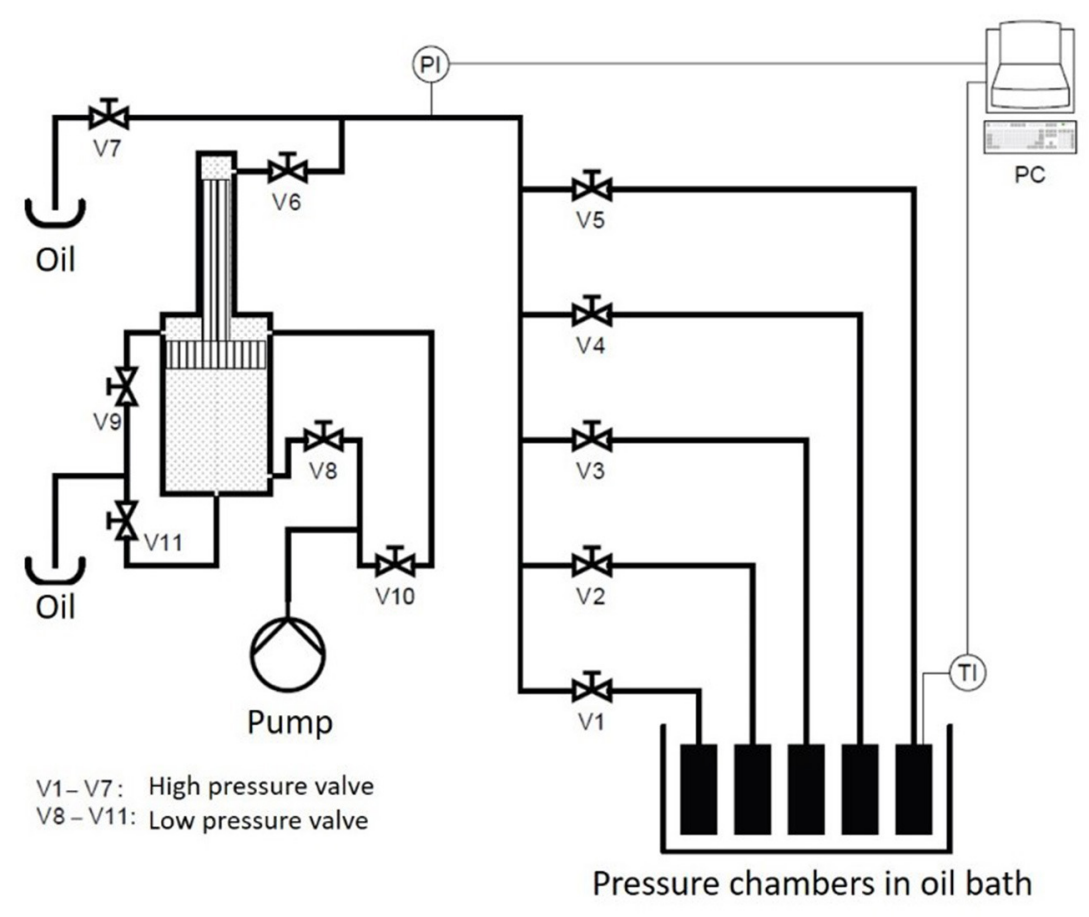

FIGURE 1 | Schematic drawing of the U111 high pressure unit.

TABLE 2 | Empirical values for the start of high-pressure treatment of the chicken rice puree (CRP).

\begin{tabular}{cccc}
\hline $\mathbf{T}_{\text {oil }}\left({ }^{\circ} \mathbf{C}\right)$ & $\mathbf{T}_{\text {ch }}\left({ }^{\circ} \mathbf{C}\right)$ & $\mathbf{T}_{\text {st }}\left({ }^{\circ} \mathbf{C}\right)$ & $\mathbf{T}_{\text {end }}\left({ }^{\circ} \mathbf{C}\right)$ \\
\hline 109 & 106 & 60 & 102 \\
111 & 108 & 62 & 104 \\
113 & 110 & 64 & 106 \\
115 & 112 & 66 & 108 \\
117 & 114 & 68 & 110 \\
119 & 116 & 70 & 112 \\
121 & 118 & 72 & 114 \\
123 & 120 & 74 & 116 \\
125 & 122 & 76 & 118 \\
127 & 124 & 78 & 120
\end{tabular}

T_oil, temperature of the oil bath; $T_{-}$ch, temperature in the sample chamber; $T_{-} s t$, temperature at the start of the pressure build-up; $T_{-}$end, target treatment temperature of the sample.

until the desired $\mathrm{F}_{0}$ value was reached in the inner chamber (at the coldest spot). The outer chamber was filled with salt water and heated by application of $\mathrm{OH}$ as well. Cooling was provided by flushing the outer chamber with cold water. When the core temperature $\left(\mathrm{T}_{1}\right)$ was below $50^{\circ} \mathrm{C}$, samples were removed, quickly put into sample containers, and immediately stored at $-30^{\circ} \mathrm{C}$.

Temperature was monitored using four polytetrafluoroethylene (PTFE)-coated K-type thermocouples
(Ellab GmbH, Gyhum, Germany), two in the inner product chamber and two in the outer chamber. The sensors in the inner chamber were placed in the geometrical center $\left(\mathrm{T}_{1}\right)$ and close to the electrode in the lower corner of the chamber $\left(\mathrm{T}_{2}\right)$. Based on preliminary trials, position $\mathrm{T}_{2}$ was chosen as a potential cold spot during $\mathrm{OH}$, due to both the conductive heat loss toward the electrode and the convective heat transfer toward the top of the chamber.

\section{Thermal Sterilization by $\mathrm{OH}$ and Retort}

Although some data from the literature suggest that sterilization by $\mathrm{OH}$ could result in an additional non-thermal inactivation of bacterial spores (33-35), data are still scarce on this topic. In our pretrials (data not shown), no additional inactivation by $\mathrm{OH}$ in carrot puree was observed. Therefore, in this study, the sole thermal sterilization effect was considered to ensure a safe and comparable $\mathrm{OH}$ sterilization process. For purposes of comparison, $\mathrm{OH}$ and the conventional retort sterilization processes were performed at the same $\mathrm{F}_{0}$ values. The common $\mathrm{C}$ value was determined as an additional indicator for the thermal load affecting the quality characteristics.

For the conventional retort sterilization, the carrot-oil model purees were preheated to $80^{\circ} \mathrm{C}$ and filled into glass jars $(230 \mathrm{ml})$, which were then sterilized in a static retort system (Type YRX 900-0 BV, dft technology GmbH, Neumünster, Germany) by spraying hot water $\left(121^{\circ} \mathrm{C}\right)$ on the jars. Retorted CRP samples (benchmark), provided by the industrial partner for further analysis, were also sterilized in glass jars $(250 \mathrm{ml})$. 
TABLE 3 | Process conditions for carrot-oil model food systems and chicken rice puree (CRP) treated by pressure-enhanced sterilization (PES) (600 MPa) and thermal references $(0.1 \mathrm{MPa})$ with the same temperature history.

\begin{tabular}{|c|c|c|c|}
\hline Sample & $\begin{array}{l}\text { Parameters } \\
\text { PES and thermal reference }\end{array}$ & Sample & $\begin{array}{l}\text { Parameters } \\
\text { PES }\end{array}$ \\
\hline Carrot-oil model food puree & $\begin{array}{l}600 \mathrm{MPa} \text { and/or } 105^{\circ} \mathrm{C}, 5 \mathrm{~min} \\
600 \mathrm{MPa} \text { and/or } 105^{\circ} \mathrm{C}, 10 \mathrm{~min} \\
600 \mathrm{MPa} \text { and/or } 110^{\circ} \mathrm{C}, 5 \mathrm{~min} \\
600 \mathrm{MPa} \text { and/or } 110^{\circ} \mathrm{C}, 10 \mathrm{~min} \\
600 \mathrm{MPa} \text { and/or } 115^{\circ} \mathrm{C}, 5 \mathrm{~min} \\
600 \mathrm{MPa} \text { and/or } 115^{\circ} \mathrm{C}, 10 \mathrm{~min}\end{array}$ & CRP & $\begin{array}{l}600 \mathrm{MPa}, 110^{\circ} \mathrm{C}, 9.9 \mathrm{~min} \\
600 \mathrm{MPa}, 112^{\circ} \mathrm{C}, 7.9 \mathrm{~min} \\
600 \mathrm{MPa}, 114^{\circ} \mathrm{C}, 6.5 \mathrm{~min} \\
600 \mathrm{MPa}, 116^{\circ} \mathrm{C}, 5.2 \mathrm{~min} \\
600 \mathrm{MPa}, 121^{\circ} \mathrm{C}, 7.0 \mathrm{~min}\end{array}$ \\
\hline
\end{tabular}

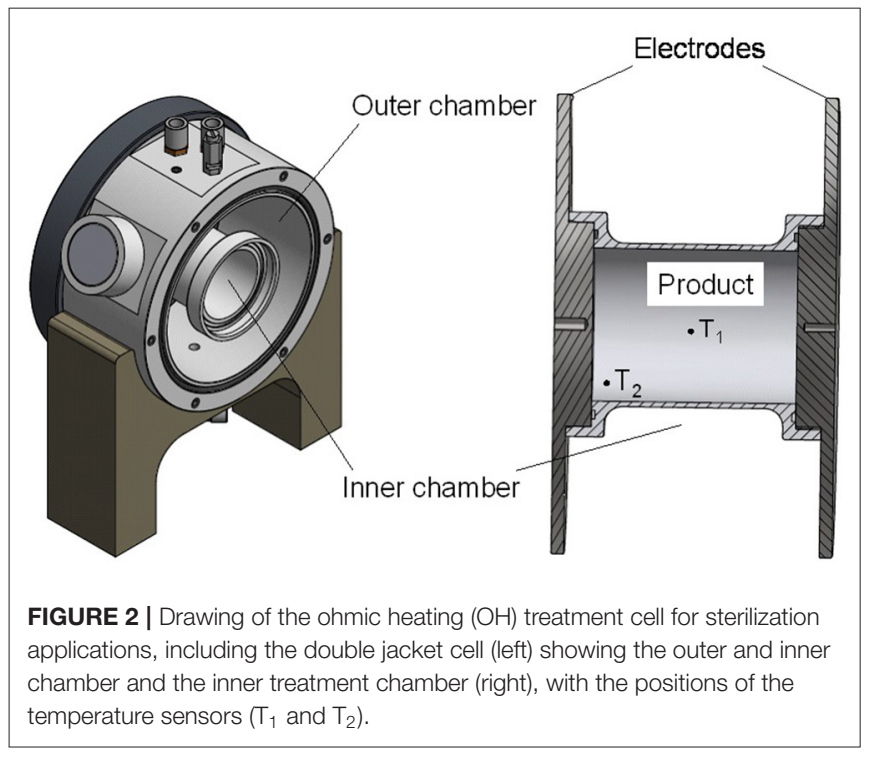

For the $\mathrm{OH}$ sterilization runs, the vegetable puree was deposited into the inner treatment chamber (Figure 2) at room temperature. The outer chamber was filled with salt water; the conductivity matched to the product. During the heating process, the salt water in the outer chamber and the product in the inner chamber were heated simultaneously to prevent cold spots close to the wall and on the contact surfaces with the electrode. As similarly reported by Zell et al. (36), a reduction in cold spots by external heating was observed, in this case by the simultaneous heating of salt water in the outer chamber.

To achieve a uniform overall thermal load, the process had to be designed in such a way that slightly higher heating rates resulted in spots close to the wall of the inner chamber. This was necessary, as the subsequent cooling step (flushing the outer chamber with cold water) cooled the volume elements of the sample close to the cylinder wall more quickly due to conventional heat transfer. An increased heating rate in the outer chamber also increased the heating rates in those areas of the inner chamber, thus achieving similar lethality values in the center $\left(\mathrm{T}_{1}\right)$ and close to the cylinder wall and the electrode in the lower corner $\left(\mathrm{T}_{2}\right)$ (Figure 2). The increased heating rate of the outer chamber was achieved by increasing the conductivity of the surrounding water.
The carrot puree (Table 1) was sterilized by $\mathrm{OH}$ and retorted at four different $\mathrm{F}_{0}$ values $\left(\mathrm{F}_{0}=3,7,14\right.$, and $\left.21 \mathrm{~min}\right)$, covering a range of $\mathrm{F}_{0}$ values used in industrial sterilization treatments.

To ensure the comparability of results, the CRP was sterilized by $\mathrm{OH}$ at the same $\mathrm{F}_{0}$ value $(7 \mathrm{~min})$ as the industrial benchmark retort sample. For the ohmic treatments, the maximum temperature varied while maintaining a constant $\mathrm{F}_{0}$ value. Thus, CRP was sterilized at maximum temperatures of 115, 121, 125, and $130^{\circ} \mathrm{C}$. In the tests, the rapid heating rates resulting from $\mathrm{OH}$ were used to quickly reach the desired temperature with the intention of reducing the thermal load. Finally, it was tested which parameters would lead to better preservation of valuable ingredients or to a minimization of processing contaminant formation: a lengthy treatment at reduced temperatures or an abbreviated treatment at higher temperatures. All runs were performed in duplicates.

\section{Value Calculation}

To be able to compare the impact of the different sterilization methods on the physiochemical properties and furan content at a comparable level of thermal damage, cooking values ( $\mathrm{C}$ values) were determined for all treatments. The $\mathrm{C}$ values $(\mathrm{min})$ were calculated from the temperatures measured in the core of the samples $\left(\mathrm{T}_{1}\right)$ according to Equation 1 (37).

$$
C=\int_{0}^{t} 10^{\left(\frac{T-T_{\text {ref }}}{z}\right)} d t
$$

with $\mathrm{t}=$ treatment time $(\mathrm{min}), \mathrm{T}=$ temperature $\left({ }^{\circ} \mathrm{C}\right), \mathrm{T}_{\text {ref }}=$ reference temperature (set to $100^{\circ} \mathrm{C}$ ) and $\mathrm{z}=$ temperature change that induces a 10 -fold change of the $\mathrm{D}$ value. A $\mathrm{z}$ value of $30^{\circ} \mathrm{C}$ was used, as similar values were used in the literature for changes in the physiochemical properties (38).

\section{Analytical Determination of Product Quality Color}

All color measurements were carried out using an image analysis system (DigiEye color measurement and imaging system, Verivide Limited, Leicester, UK). The CRP samples were spread uniformly in the bottom of a Petri dish and placed in the middle of a photo box to guarantee reproducible light conditions. Photos were taken using a digital camera (D90, Nikon Corp., Tokyo, Japan). Based on the images, $\mathrm{L}^{*}, \mathrm{a}^{*}$, and $\mathrm{b}^{*}$ values were determined using the integrated software (Digipix, Verivide Limited, Leicester, UK). 
From the obtained $\mathrm{L}^{*}, \mathrm{a}^{*}$, and $\mathrm{b}^{*}$ values, $\Delta \mathrm{E}$ values were calculated in reference to the untreated sample for the retort benchmark samples, ohmically heated samples, and PEStreated samples (Equation 2). This value indicates the overall difference between two colors. According to the literature, for $\Delta \mathrm{E}$ values above 2.3 , a slightly noticeable color difference can be perceived (39).

$$
\Delta E_{S, R}=\sqrt{\left(L_{S}^{*}-L_{R}^{*}\right)^{2}+\left(a_{S}^{*}-a_{R}^{*}\right)^{2}+\left(b_{S}^{*}-b_{R}^{*}\right)^{2}}
$$

with $L^{*}, a^{*}$, and $b^{*}$ values determined from a certain sample (S) compared to a defined reference $(\mathrm{R})$ - in this case, the untreated CRP sample.

\section{Texture}

Textural profile analyses (TPAs) of the PES-treated CRP samples were conducted using a texture analyzer $(1 \mathrm{kN}$ Zwicki, MPMS 50302, Zwick GmbH \& Co. KG, Ulm, Germany) according to Shim and Lim (40). Texture parameters such as firmness, adhesiveness, cohesiveness, springiness, and gumminess were measured in triplicate. The following instrumental test parameters were used: mode was forced in compression; load cell value was $1 \mathrm{kN}$; trigger type was $0.1 \mathrm{~N}$; and a cylindrical plastic probe ( $25 \mathrm{~mm}$ diameter, $40 \mathrm{~mm}$ height) was used. An aliquot of each sample $(\sim 100 \mathrm{~g})$ was analyzed in a plastic sample beaker (50 $\mathrm{mm}$ diameter, $105 \mathrm{~mm}$ height) resulting in a sample height of around $50 \mathrm{~mm}$. The entry depth of the probe was set to $10 \mathrm{~mm}$ using a test speed of $50 \mathrm{~mm} / \mathrm{min}$. Samples were analyzed at room temperature. To determine the texture of the samples, the surface layer of each sample was smoothened, and the test cycle was started recording the force-time curve. The force-time curve was further evaluated to determine the texture parameters using an octave code that had been programmed in-house according to the interpretation rules for textural profile analysis.

A TPA of both the ohmically and the benchmark retort sterilized samples were done with the same parameters as for the PES samples using a Stable Microsystems texture analyzer (Texture Analyzer XTplus, Stable Microsystems Ltd, Godalming, England). The force data were recorded, and TPA parameters (i.e., firmness, adhesiveness, cohesiveness, springiness, and gumminess) were calculated by the Exponent Texture analyzer software (Stable Micro Systems Ltd.).

\section{Analysis of Food Processing Contaminants Furans}

Head space solid-phase microextraction (HS-SPME) with gas chromatography coupled to high-resolution time of flight mass spectrometer Pegasus HRT (LECO, USA) was used for the determination of furan and its derivates (2-methylfuran, 3-methylfuran, 2,5-methyfuran). Sample preparation and measurement were performed using a slightly modified method by Hradecky et al. (30). The analytical approach represents a certified accredited method according to $\mathrm{EN}$ ISO/IEC 17025:2018.

\section{Acrylamide}

Ultrahigh-performance liquid chromatography using an Acquity liquid chromatograph system (Waters, USA) coupled to a
XEVO TQ-S Tandem Quadrupole Mass Spectrometer (Waters, USA) was used for detection and quantification of acrylamide. Analytical approach was conducted as described by Forstova et al. (41). The analytical approach represents a certified accredited method according to EN ISO/IEC 17025:2018.

\section{3-MCPD Esters}

Ultrahigh-performance liquid chromatography (U-HPLC) using an Acquity Ultra high-pressure liquid chromatograph system (Waters, USA) coupled to high-resolution orbitrap mass spectrometer Exactive ${ }^{\mathrm{TM}}$ (Thermo Fisher Scientific, Bremen, Germany) was used for the determination and quantification of individual 3-monochloropropane-1,2-diol (3-MCPD) bound in diesters (expressed as 3-MCPD esters). Sample preparation and measurement were performed with a slight modification described by Moravcova et al. (42). The analytical approach represents a certified accredited method according to EN ISO/IEC 17025:2018.

\section{Analysis of Carotenoids}

HPLC coupled to diode array detector (DAD) was used for the determination of carotenoids. The analytical approach was performed as described by Bhave et al. (43) with a slight modification including alkaline hydrolysis prior to carotenoid extraction. Briefly, $2 \mathrm{ml}$ of a mixture of ethanol/acetone $(6: 4, v / v)$ with $0.2 \%(w / w)$ of tert-butyl-hydroxytoluene (t-BHT) was added to $1 \mathrm{~g}$ of sample. The mixture was vigorously shaken. Afterwards, $6 \mathrm{ml}$ of hexane followed by $5 \mathrm{ml}$ of the ethanol/acetone mixture was added and shaken for $5 \mathrm{~min}$. A solution of $\mathrm{KOH}(5 \mathrm{~mL})$ was added and left for $18 \mathrm{~h}$.

The samples were neutralized with $\mathrm{Na}_{2} \mathrm{SO}_{4}$ after hydrolysis, and another $10 \mathrm{ml}$ of hexane was added, shaken for $2 \mathrm{~min}$, and centrifuged at $10,000 \mathrm{~g}$ for $5 \mathrm{~min}$. The extraction of carotenoids was repeated with $10 \mathrm{ml}$ of hexane, altogether three times. The hexane layers were collected into an evaporating flask and evaporated to dryness on a vacuum rotary evaporator. The residue was then reconstituted in $4 \mathrm{ml}$ of ethanol/acetone $(6: 4, v / v)$ with $0.2 \%(w / w)$ of t-BHT and microfiltered by $0.2 \mu \mathrm{m}$ polyvinylidene fluoride (PVDF) membrane filter (43).

\section{RESULTS AND DISCUSSION Evaluation of Different Sterilization Processes}

All three technologies, PES, OH, and conventional retort, were successfully applied to sterilize the carrot-oil model purees and the CRP. OH and traditional retort samples were sterilized by the same $\mathrm{F}_{0}$ values, carrot-oil purees between $\mathrm{F}_{0}=3-21 \mathrm{~min}$, and CRP at $\mathrm{F}_{0}=7 \mathrm{~min}$. PES samples were sterilized by $\mathrm{p}$, $\mathrm{T}, \mathrm{t}$ combinations that equaled a $12 \log _{10}$ inactivation of $B$. amyloliquefaciens (Supplementary Material 2.1). The calculated $\mathrm{C}$ values based on the core temperatures of the samples during the treatments were used solely to estimate the thermal impact of the treatments with regards to the cooking damage and to compare the obtained results. 
The retort sterilization resulted in a slow heating rate, demonstrating the necessity of preheating of the product to $80-$ $85^{\circ} \mathrm{C}$ prior to sterilization. These conditions represent common practice in the industry. On the other hand, $\mathrm{OH}$ treatments resulted in a more rapid heating of the puree samples, rendering the separate preheating step obsolete. To illustrate this, the core temperature profiles during the retort and $\mathrm{OH}$ sterilization $\left(\mathrm{F}_{0}=3-21 \mathrm{~min}\right)$ of the carrot-oil model medium are shown in Figure 3.

Additionally, the time needed to reach the target $\mathrm{F}_{0}$ values and the resulting $\mathrm{C}$ values of all treatment combinations are summarized in Table 4. As expected, both the treatment time and the $\mathrm{C}$ values increased with increasing $\mathrm{F}_{0}$ values in the carrot-oil model medium treated with both technologies. However, for $\mathrm{OH}$, treatment time and resulting $\mathrm{C}$ values could be significantly reduced at all four $\mathrm{F}_{0}$ values compared with those of the retort treatment. These results can be linked to the more rapid and uniform heating profiles observed during the $\mathrm{OH}$ treatment. The reduction in treatment time and $\mathrm{C}$ value relative to the retort treatment was higher for the lower $\mathrm{F}_{0}$ values. At $\mathrm{F}_{0}=3 \mathrm{~min}$ and $7 \mathrm{~min}$, the reduction in the time to reach the respective $\mathrm{F}_{0}$ value was over $60 \%$; at $\mathrm{F}_{0}=$ $21 \mathrm{~min}$, it was $51 \%$. For the $\mathrm{C}$ value, the reduction by $\mathrm{OH}$ treatment compared to the retort treatment was $41 \%$ at $\mathrm{F}_{0}$ $=3 \mathrm{~min}$, while at $\mathrm{F}_{0}=21 \mathrm{~min}$, the reduction was only $21 \%$. Those observations were expected for higher $\mathrm{F}_{0}$ values (also for $\mathrm{OH}$ treatment); thus, longer holding times at $121^{\circ} \mathrm{C}$ were necessary, which contributed to enhanced treatment times and $\mathrm{C}$ values. To better benefit from the $\mathrm{OH}$ treatment for the higher $\mathrm{F}_{0}$ values, higher maximum temperatures $\left(\mathrm{T}_{\max }\right)$ could considerably shorten the temperature holding time, therefore further enhancing the thermal load reduction relative to the retort treatment.

Therefore, to reduce the overall thermal load for the CRP samples, varying $\mathrm{T}_{\max }$ for the $\mathrm{OH}$ treatments were investigated. As expected, with higher $\mathrm{T}_{\max }$ for the $\mathrm{OH}$ treatments, time period to reach a $\mathrm{F}_{0}=7 \mathrm{~min}$ and $\mathrm{C}$ values decreased (Table 5). However, this was only observed until a $\mathrm{T}_{\max }$ of $125^{\circ} \mathrm{C}$. Due to the slow cooling of the samples with a $\mathrm{T}_{\max }$ of $130^{\circ} \mathrm{C}, \mathrm{F}_{0}$ values were above $\mathrm{F}_{0}=7 \mathrm{~min}$, and therefore, the $\mathrm{C}$ values were also higher compared to $\mathrm{T}_{\max }$ of $125^{\circ} \mathrm{C}$. Compared to industrial benchmark retort sterilization, the time period needed to reach $\mathrm{F}_{0}=7 \mathrm{~min}$ could be reduced by a maximum of $71 \%$, including a reduction of $57 \%$ for the attained $\mathrm{C}$ value, which was determined for the $\mathrm{OH}$ treatment with a $\mathrm{T}_{\max }$ of $125^{\circ} \mathrm{C}$. Furthermore, in terms of $\Delta \mathrm{T}$ within the samples during heating, the $\mathrm{OH}$ treatment exhibited a clearly superior heating uniformity. Benchmark treatment resulted in an over-processing of the volume elements on the outside and lead also to higher $\mathrm{F}_{0}$ and $\mathrm{C}$ values in these areas. Similar results could be attained for $\mathrm{F}_{0}$ and $\mathrm{C}$ values using $\mathrm{OH}$ (Figure 4).

A more rapid and efficient heating of vegetable and fruit purees by batch $\mathrm{OH}$ was also reported by several other authors $(44,45)$. Yildiz et al. (46) reported up to $400 \%$ decrease in the heating time period required for spinach puree by $\mathrm{OH}$ (up to 40 $\mathrm{V} / \mathrm{cm}$ ) as compared to that of conventional heating. The same working group also investigated the blanching of pea puree by $\mathrm{OH}$ and found similar results, namely, that $\mathrm{OH}$ could reduce the necessary blanching time sixfold (47).

The PES sterilization treatments resulted in even lower $\mathrm{C}$ values (Table 5). The synergistic inactivation effect of the applied pressure and temperature allowed for a reduction in both the processing temperature and the thermal load, compared to those of the retorted carrot-oil puree and the industrial benchmark CRP samples (Supplementary Material 2.1). For the CRP, it is evident that the thermal load applied to the product, depending on the process (except for PES $121^{\circ} \mathrm{C}$, $7 \mathrm{~min}$ ), was $69-79 \%$ lower for the industrial benchmark process. Even for treatments with comparable holding times of $7 \mathrm{~min}$ at $121^{\circ} \mathrm{C}$, the PES sample and the thermal reference sample exhibited differing $\mathrm{C}$ values. This was due to different $\mathrm{T}, \mathrm{t}$ profiles corresponding to variable heating and cooling patterns. The thermal load of the PES process was $36 \%$ lower in comparison to that of the industrial benchmark process. The selected parameters from Table 5 are the basis of all other conducted trials.

Hence, the results show that with both volumetric sterilization technologies ( $\mathrm{OH}$ and $\mathrm{PES}$ ), a reduction in the overall thermal load through a more uniform and efficient heating mode was possible. Both technologies were able to provide distinctly higher heating rates and possess, therefore, the potential fora radical reduction in process time requirements.

In scientific literature, additional non-thermal microbial inactivation effects attributed to $\mathrm{OH}$ were discussed (33, 35, 48). However, until now, the available data are contradictory. Potential additional inactivation mechanisms caused by the electric field during $\mathrm{OH}$ were not considered in this study. The reduction in the applied thermal load compared to that of the retort treatment was therefore only due to the more rapid and uniform heating performed by $\mathrm{OH}$ sterilization, which can be seen in the lower $\mathrm{C}$ values.

For PES, on the other hand, there already exists a substantial amount of data on the synergistic inactivation effect of the applied pressure and temperature on spore inactivation (27, 49, 50). This was also acknowledged by the FDA (US Food and Drug Administration) approval for PES treatment, with temperature $<121.1^{\circ} \mathrm{C}$ and pressure $600 \mathrm{MPa}(13)$.

Subsequently, lower C values could be achieved for PES sterilization, through a distinct reduction in temperature and holding time. However, even for samples treated at the same $F_{0}$ values, lower $C$ values resulted for PES treatments compared to those of conventional retort and $\mathrm{OH}$ due to rapid and uniform adiabatic heating and cooling. Currently, PES treatment would be feasible for certain niche products that need to be sterilized in-pack and for which a highquality outcome is the aim, e.g., nutraceuticals as well as baby food. $\mathrm{OH}$ is more suitable for applications requiring a high throughput and an out-of-pack treatment, e.g., soups, sauces, fruit preparations, etc. At the present time, to the knowledge of the authors, there are no commercial concepts for in-pack $\mathrm{OH}$ treatments. 

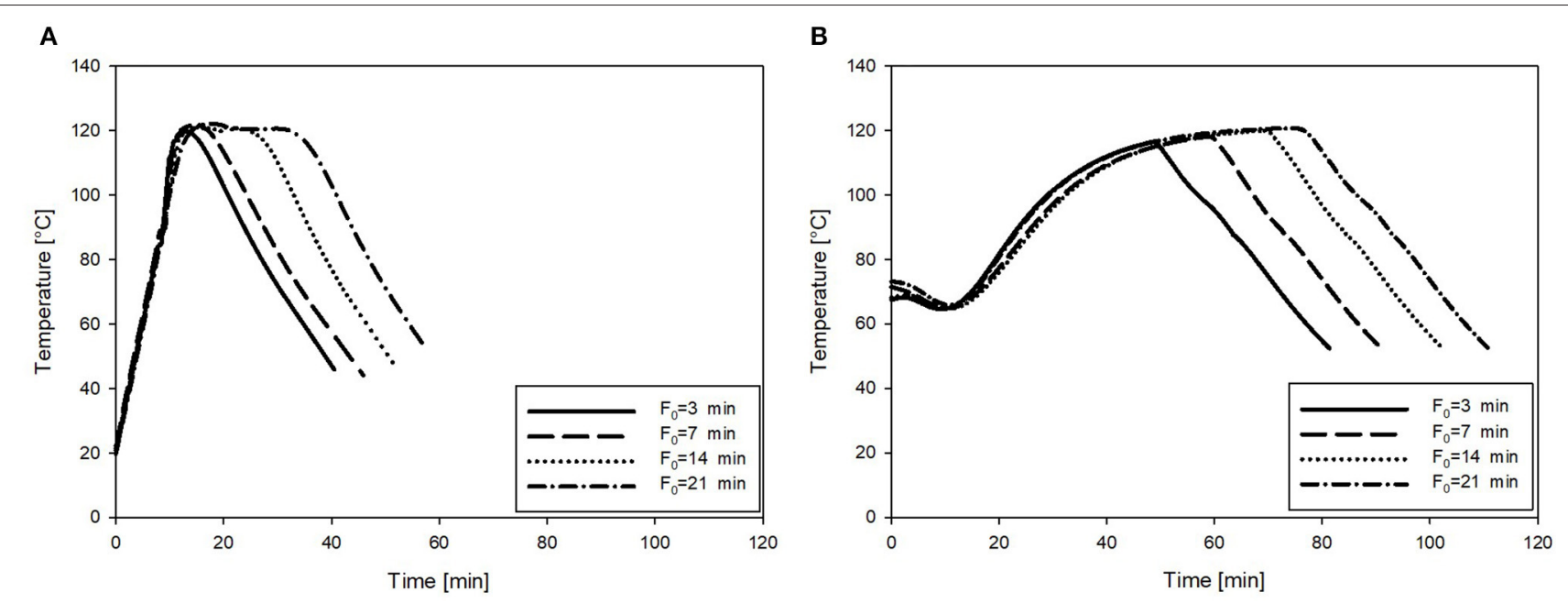

FIGURE 3 | Exemplary temperature profiles of the carrot-oil puree sterilized at $\mathrm{F}_{0}=3,7,14$, and 21 min. $(\mathbf{A})$ Treated by $\mathrm{OH}$ and $(\mathbf{B})$ heated by the conventional retort.

TABLE 4 | Time to reach the target $F_{0}$ value and resulting $C$ values of carrot-oil model medium sterilized by ohmic heating $(\mathrm{OH})$ or conventional retort.

\begin{tabular}{lccrrr}
\hline & \multicolumn{2}{c}{ Time (min) } & & \multicolumn{2}{c}{ C value (min) } \\
\cline { 2 - 3 } \cline { 5 - 6 } F $_{\mathbf{n}}$ value (min) & OH & Retort & & OH & Retort \\
\hline 3 & $19.2 \pm 5.3$ & $49.6 \pm 3.6$ & & $43.3 \pm 4.1$ & $73.3 \pm 16.4$ \\
7 & $23.5 \pm 3.7$ & $63.7 \pm 2.2$ & & $67.0 \pm 6.4$ & $104.5 \pm 12.4$ \\
14 & $31.2 \pm 2.4$ & $73.4 \pm 0.9$ & & $100.7 \pm 5.3$ & $145.0 \pm 8.3$ \\
21 & $40.1 \pm 7.1$ & $82.8 \pm 7.1$ & & $150.4 \pm 15$ & $190.0 \pm 12.6$ \\
\hline
\end{tabular}

\section{Impact of Sterilization Treatments on the Formation of Food Processing Contaminants}

Furan and its derivates were analyzed in sterilized carrot-oil model purees and the CRP. Additionally, the treated carrotoil model purees were also analyzed for the formation of 3monochloropropane-1,2-diol (3-MCPD) esters. However, due to the low processing temperatures, the treatment types had no influence on the levels of 3-MCPD esters. The detected levels of 3-MCPD esters were significantly below the detection limit of 0.9 $\mu \mathrm{g} / \mathrm{kg}$ in all samples. Therefore, the analysis of 3-MCPD esters in the CRP samples were not considered.

Furthermore, the formation of acrylamide was analyzed in CRP samples. Acrylamide levels for all analyzed CRP samples were below the limit of quantification of $30 \mu \mathrm{g} / \mathrm{kg}$. These findings are in accordance with Commission Regulation (EU) 2017/2158, where benchmark levels of acrylamide in baby food was established to $40 \mu \mathrm{g} / \mathrm{kg}$ (51).

\section{Furan and Methylfuran Formation in Model Matrices}

Currently, data provided by scientific literature concerning the amounts of furan and its methyl derivates 2-methyl-, 3methyl-, and 2,5-dimethylfuran (2-MF, 3-MF, and 2,5-DMF) is notably scarce. This is why the European Food Safety Authority (EFSA) has issued a call for the collection of data recording the occurrence of these harmful substances in food (52). It was postulated that exposure to 2-MF, but not 3-MF, would be additive to furan exposure in terms of health consequences from their consumption (53). The formation pathway of methylfurans is connected to the furan pathway since both can have the same precursors (54-56). It is still unknown how the system shifts to either methylfurans or to furan. Maga and Katz (54) postulated that the formation could be dependent upon the precursors.

The content of olive oil used in the model food puree was expected to contain distinct precursors for the formation of furan and its derivates. Other possible contributors to the formation of furan and possible derivates are carotenoids, reducing sugars, as well as proteins from carrots $(\sim 0.9 \mathrm{~g}$ per $100 \mathrm{~g})(57)$, but also polyunsaturated fatty acids present in the oil used for puree preparation. To the best knowledge of the authors, there is currently no record of studies regarding the formation of methylfurans performed under PES or OH conditions.

As mentioned in Sterilization Treatments, the carrot-oil model food puree (Tables 1, 3) was sterilized through PES (including thermal references), as well as through $\mathrm{OH}$ and conventional retort, in order to fine tune the analytical method for the quantification of furan and it derivates. The idea of the model food systems is to validate the method and analysis. The system also allows for the creation of a product that is not unlike a real product but specifically contains various potent precursors [e.g., polyunsaturated fatty acids (PUFAs); especially linoleic acid (C18:2) of which rapeseed oil contains $~ 20 \%$ and olive oil $\sim 7 \%$ (58); reducing sugar, carotenoids, vitamin $C$, etc.] to form furan. The formation pathway of furan under thermal conditions is quite well-known, and some publications concerning the influence of PES and thermal treatments on the formation are available $(26,55,59-64)$.

In the untreated model purees, the content of furan and methylfurans was below the detection limit $(0.2 \mu \mathrm{g} / \mathrm{kg})$. 
TABLE 5 | C values and actually reached $F_{0}$ values of chicken rice puree (CRP) sterilized by ohmic heating (OH), industrial benchmark retort, and pressure-enhanced sterilization (PES).

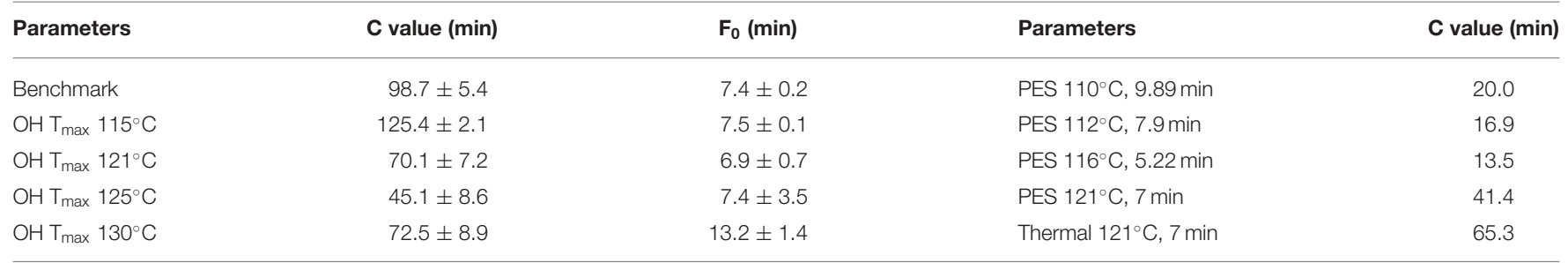

PES parameter combinations provided at least a $12 \log _{10}$ inactivation of Bacillus amyloliquefaciens.
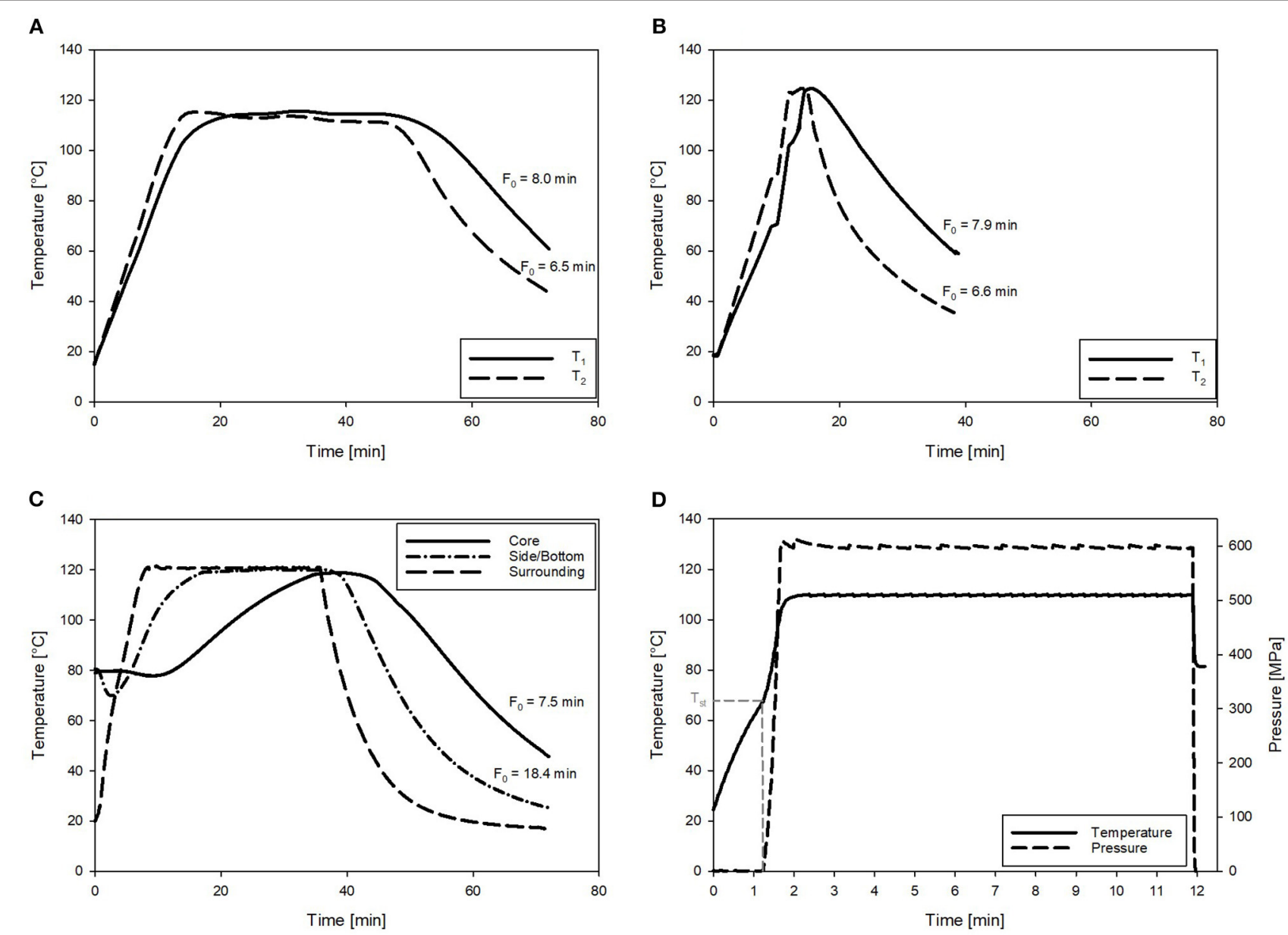

FIGURE 4 | Exemplary temperature profiles and corresponding $F_{0}$ values of the chicken rice puree (CRP) sterilized by ohmic heating $(\mathrm{OH})$, retort, and pressure-enhanced sterilization (PES). (A) $\mathrm{OH}$ with $T_{\max }=115^{\circ} \mathrm{C}$. (B) $\mathrm{OH}$ with $\mathrm{T}_{\max }=125^{\circ} \mathrm{C}\left(\mathrm{T}_{1}\right.$ and $\mathrm{T}_{2}$ are referring to temperature sensor positions in the core and close to the electrode as defined in Figure 2). (C) Retort sterilization with one sensor in the geometrical center and one in the lower corner of the glass jar. (D) PES sterilization at $600 \mathrm{MPa}, 110^{\circ} \mathrm{C}$ for $9.89 \mathrm{~min}$. With the pressure-temperature curve and $\mathrm{T}_{\mathrm{st}}$ referring to the start temperature for pressure build-up.

However, furan formation was observed after processing. Figures $\mathbf{5 A}, \mathbf{B}$ show the formation of furan and its derivates in samples treated by PES (under pressure $600 \mathrm{MPa}$ ) and solely heated (thermal reference, no pressure used), with the same temperature time combinations. The heating time of PES and thermal reference samples was controlled to be comparable.
A minimal amount $(\leq 0.8 \mu \mathrm{g} / \mathrm{kg})$ of furan and 2- or 3-MF was formed under PES conditions for the carrot puree containing olive oil, although, to some extent, minor formation occurred for the carrot puree with rapeseed oil (Figure 5B) at $115^{\circ} \mathrm{C}, 5$ and $10 \mathrm{~min}, 600 \mathrm{MPa}$. Compared to the olive oil, higher levels of furan and its derivates (up to $4 \mu \mathrm{g} / \mathrm{kg}$ ) were found in the carrot puree containing rapeseed oil. However, these levels are still quite 

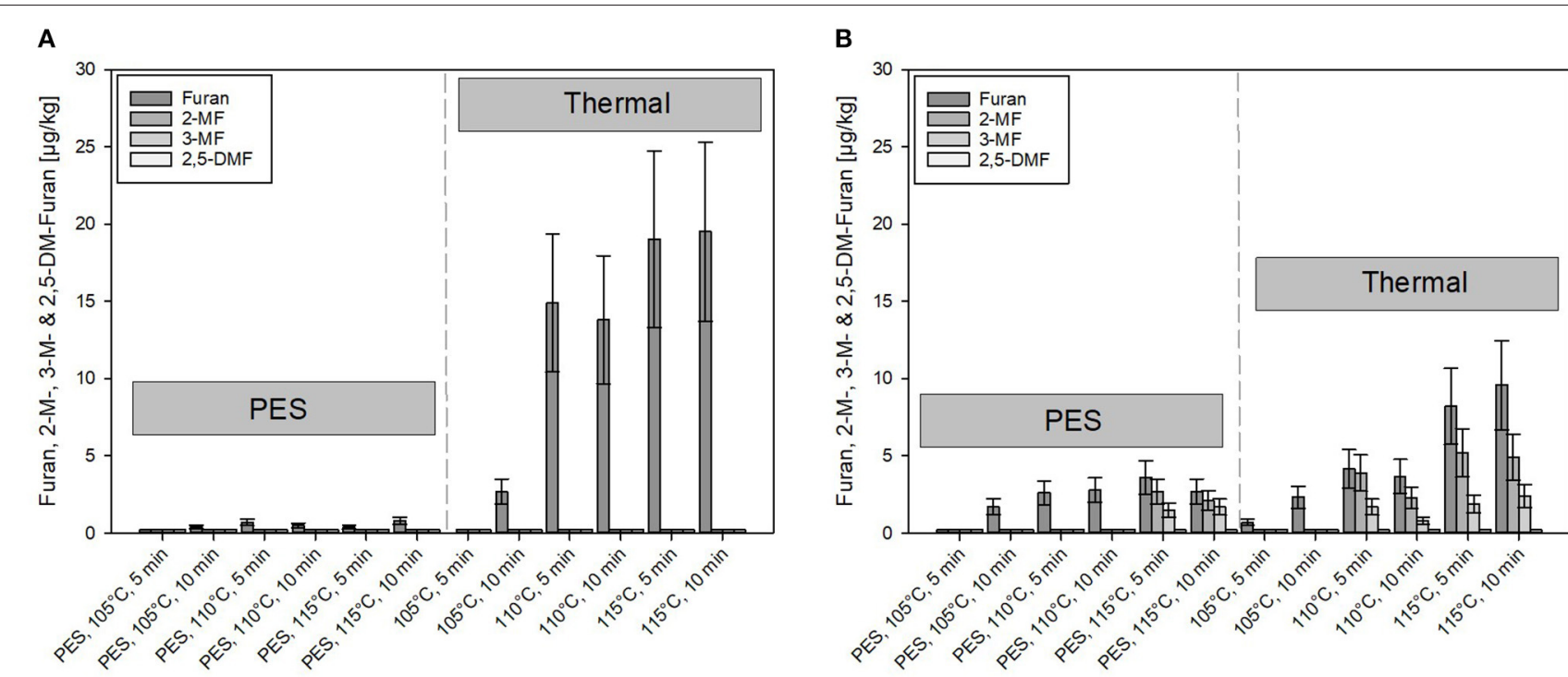

FIGURE 5 | Comparison of furan and its derivates formed under pressure-enhanced sterilization (PES) (600 MPa) and solely thermal conditions. (A) Carrot puree with olive oil and (B) carrot puree with rapeseed oil. Error bars represent 95\% confidence interval.

low compared to published data on occurrence of furan and its derivates in jarred baby food preparations (65).

In comparison, under solely thermal conditions, furan formation starts occurring at $105^{\circ} \mathrm{C}, 10 \mathrm{~min}$ under solely thermal conditions. At $110^{\circ} \mathrm{C}$, the formation starts to increase with time and temperature. The threshold temperature for the furan formation was reported to be at $110^{\circ} \mathrm{C}(2,66)$. Furthermore, the formation of furan under thermal conditions was almost doubled in the system containing olive oil (Figure 5A). Whereas, the formation of 2- and 3-MF did not exist in the aforementioned product. Notably, 2-MF was present in the puree containing rapeseed oil processed at temperatures $\geq 110^{\circ} \mathrm{C}$. This could be attributed to the presence of precursors in the preprocessed oils. Due to the pretreatment of, e.g., rapeseed oils (bleaching, neutralization, deodorization, etc.), where often high temperatures $\left(105^{\circ} \mathrm{C}\right.$ for bleaching and $270^{\circ} \mathrm{C}$ for deodorization) are involved, this can lead to lipid oxidation and to the occurrence of, e.g., 2-pentanal and 2-hexanal (67). Adams et al. (67) showed that these compounds can be triggered by amino acids or proteins, which are present in the food system, to react to 2MF and 2-alkylfuran. The theory was also postulated by Märk et al. (61). This could possibly explain why derivates of furan are formed in the system containing rapeseed oil, rather than furan itself.

The mitigation effect of PES on the formation of furan can be attributed to the lower thermal load applied and the Le Chatelier's principle, which influences the reaction pathway to some extent $(26,64,68)$.

Considerably higher content of furan and its derivates were determined in the carrot-model food systems sterilized by $\mathrm{OH}$ and conventional retort (Figure 6). In general, with increasing thermal load, i.e., with higher $\mathrm{F}_{0}$ values, higher furan content was found in the samples processed by the retort, whereas lower levels of furan were found in ohmic-sterilized samples than in the retort-sterilized purees. Furan levels in the $\mathrm{OH}$ carrot olive oil samples were, however, consistently higher than those found in the PES samples.

After the retorted purees containing rapeseed oil were treated with the highest thermal load of $\mathrm{F}_{0}=21 \mathrm{~min}(33.1 \mu \mathrm{g} / \mathrm{kg})$, furan formation levels were almost triple those detected after treatments with the lowest thermal load of $\mathrm{F}_{0}=3 \mathrm{~min}$ (13.5 $\mu \mathrm{g} / \mathrm{kg}$ ). The levels of furan at $\mathrm{F}_{0}=14$ min were, surprisingly, slightly higher than those of the samples sterilized with a $\mathrm{F}_{0}=$ $21 \mathrm{~min}$. With $\mathrm{F}_{0}=14 \mathrm{~min}$, furan levels of 39.2 and $44.4 \mu \mathrm{g} / \mathrm{kg}$ were analyzed in the puree containing olive oil and rapeseed oil, respectively. Differences between the purees containing rapeseed oil and olive oil were within the determination uncertainty. Therefore, the results are not in accordance with furan formation in the thermal PES references done in the lab scale, where an impact of the two different oils was determined. It was assumed that the more severe heat treatments during the retort treatments and the resulting overall higher furan levels overshadowed the impact of the oils. In scientific literature, levels of furan between 6.3 and $85.6 \mu \mathrm{g} / \mathrm{kg}$ were reported in commercially available vegetable-based purees, which is in general accordance with the results obtained in this study (65). In addition, the reported level of furan in strained carrots (intended as baby food) with $27.8 \mu \mathrm{g} / \mathrm{kg}$ by Becalski et al. (53) is in alignment with the obtained results.

Under $\mathrm{OH}$ conditions, distinctly lower furan and 2- or 3-MF was formed as compared to those found in retort conditions. Furan found in the carrot-oil purees sterilized by $\mathrm{OH}$ ranged from $7.9 \mu \mathrm{g} / \mathrm{kg}\left(\mathrm{F}_{0}=3 \mathrm{~min}\right)$ to a maximum of $13.6 \mu \mathrm{g} / \mathrm{kg}\left(\mathrm{F}_{0}\right.$ $=21 \mathrm{~min})$, a reduction of $64 \%$ at $\mathrm{F}_{0}=3 \mathrm{~min}$, and a reduction of $41 \%$ at $\mathrm{F}_{0}=21 \mathrm{~min}$ as compared to the retort samples. The higher relative reduction rate at lower $\mathrm{F}_{0}$ values is in accordance 

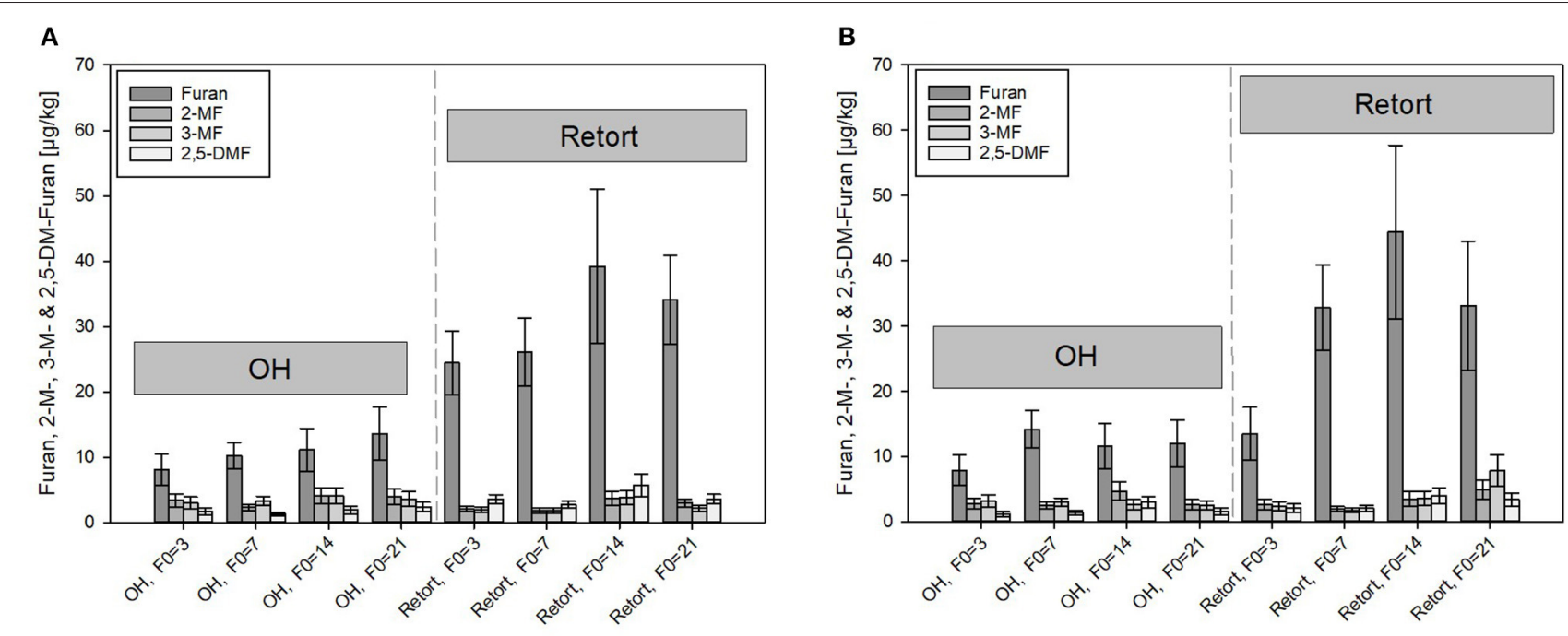

FIGURE 6 | Comparison of furan and its derivates formed under ohmic heating $(\mathrm{OH})$ and conventional retort treatment. (A) Carrot puree with olive oil and (B) carrot puree with rapeseed oil. Error bars represent $95 \%$ confidence interval.

with the determined $\mathrm{C}$ values and due to the lower holding times at temperatures above $110^{\circ} \mathrm{C}$, which was reported to be the threshold temperature for furan formation (66). In the $\mathrm{OH}$ samples, the furan content increased only slightly with higher $\mathrm{F}_{0}$ values. The observations are therefore in good accordance with results from Hradecky et al. (30), who also reported significantly lower furan levels in carrot-based purees sterilized by $\mathrm{OH}$ as compared to those of conventional retort sterilization. The authors also reported only a minor impact of the sterilization value on the furan formation for the $\mathrm{OH}$ treatment. The reduced furan formation was linked to the uniform and rapid heating nature of the $\mathrm{OH}$ treatment, which allows a reduction in the overall thermal load. However, although care has been taken, the sample handling could have an impact on the furan content in the $\mathrm{OH}$ samples. After cooling inside the $\mathrm{OH}$ chamber, purees were transferred as rapidly as possible to small sample containers $(100 \mathrm{ml})$ and immediately stored at $-30^{\circ} \mathrm{C}$. A partial evaporation of furan and its derivates during the transfer, due to their volatile nature, cannot be excluded. In order to avoid volatilization effects, in-pack $\mathrm{OH}$ sterilization treatments need to be conducted to further investigate the impact of $\mathrm{OH}$ on the furan formation as opposed to furan formation in the conventional retort. Similar observations were reported when the furan formation for ultrahigh temperature (UHT, continuous heating)-treated foods was investigated. Compared to retorted samples, lower furan formation, and almost no increasing furan levels with increasing $\mathrm{F}_{0}$ values were observed (69). This is probably linked to faster heating rates of an open system application.

In general, lower levels of the furan derivates (2- and 3-MF and 2,5-DMF) compared to furan were formed in all treated purees. The concentrations of the derivates in the retorted samples were in the range of $2.1-7.9 \mu \mathrm{g} / \mathrm{kg}$. Again, the thermal load affected the formation of the compounds. At $\mathrm{F}_{0}=21 \mathrm{~min}$, distinctly higher levels of all three derivates were detected as compared to $\mathrm{F}_{0}=$
3 min. Similar to furan, the formation of the methylfurans was not affected by the presence of the two different oil types.

\section{Furan and Methylfuran Formation in CRP}

In the CRP samples, lower overall furan levels were found as compared to the carrot-oil model purees. One possible reason for this could be the higher water content and therefore lower concentration of precursors (carotenoids, carbohydrates, proteins, etc.) available in the CRP. Interestingly, significantly higher 2,5-DMF levels were found in the OH-treated and industrial benchmark purees, and 2,5-DMF was also the dominant process contaminant identified in CRP. The results of the furan formation (including its derivates) in the PES- and $\mathrm{OH}$-treated samples are shown in Figures 7A,B, respectively. Analyzed $\mathrm{OH}$ samples (with different maximum temperatures) and the industrial sterilized sample (benchmark) equaled a $\mathrm{F}_{0}=$ $7 \mathrm{~min}$ (except $\mathrm{OH} \mathrm{T}_{\max }=130^{\circ} \mathrm{C}$ that equaled to $\mathrm{F}_{0}=13.2 \mathrm{~min}$ ). All PES treatments theoretically lead to a $B$. amyloliquefaciens inactivation of $12 \log _{10}$.

Nominal amounts $(\leq 1.5 \mu \mathrm{g} / \mathrm{kg})$ of furan and derivates were found in PES samples even under sterilization conditions equal to the industrial benchmark $\left(121^{\circ} \mathrm{C}, 7 \mathrm{~min}\right)$. Distinctly higher amounts of furan and especially 2,5-DMF were determined in thermally (benchmark and $\mathrm{OH}$ ) treated products. Levels between 2 and $3 \mu \mathrm{g} / \mathrm{kg}$ of furan, 2-MF, and 3-MF were detected in the $\mathrm{OH}$-sterilized samples, significantly higher levels than occurred in the PES samples but significantly lower levels than occurred in the benchmark samples $(9.4 \pm 1.5 \mu \mathrm{g} / \mathrm{kg}$ ) (Figure 7). In the benchmark samples, $2-\mathrm{MF}(5.5 \pm 0.8 \mu \mathrm{g} / \mathrm{kg})$ and 3-MF $(2.8 \pm$ $0.7 \mu \mathrm{g} / \mathrm{kg}$ ) levels were significantly lower than the formed furan. In the puree examined, the main contributors to the formation of furan and its derivates were, based on the recipe of CRP, probably carrots (carotenoids and sugars) and chicken meat (proteins/amino acids). The presence of chicken meat, however, 

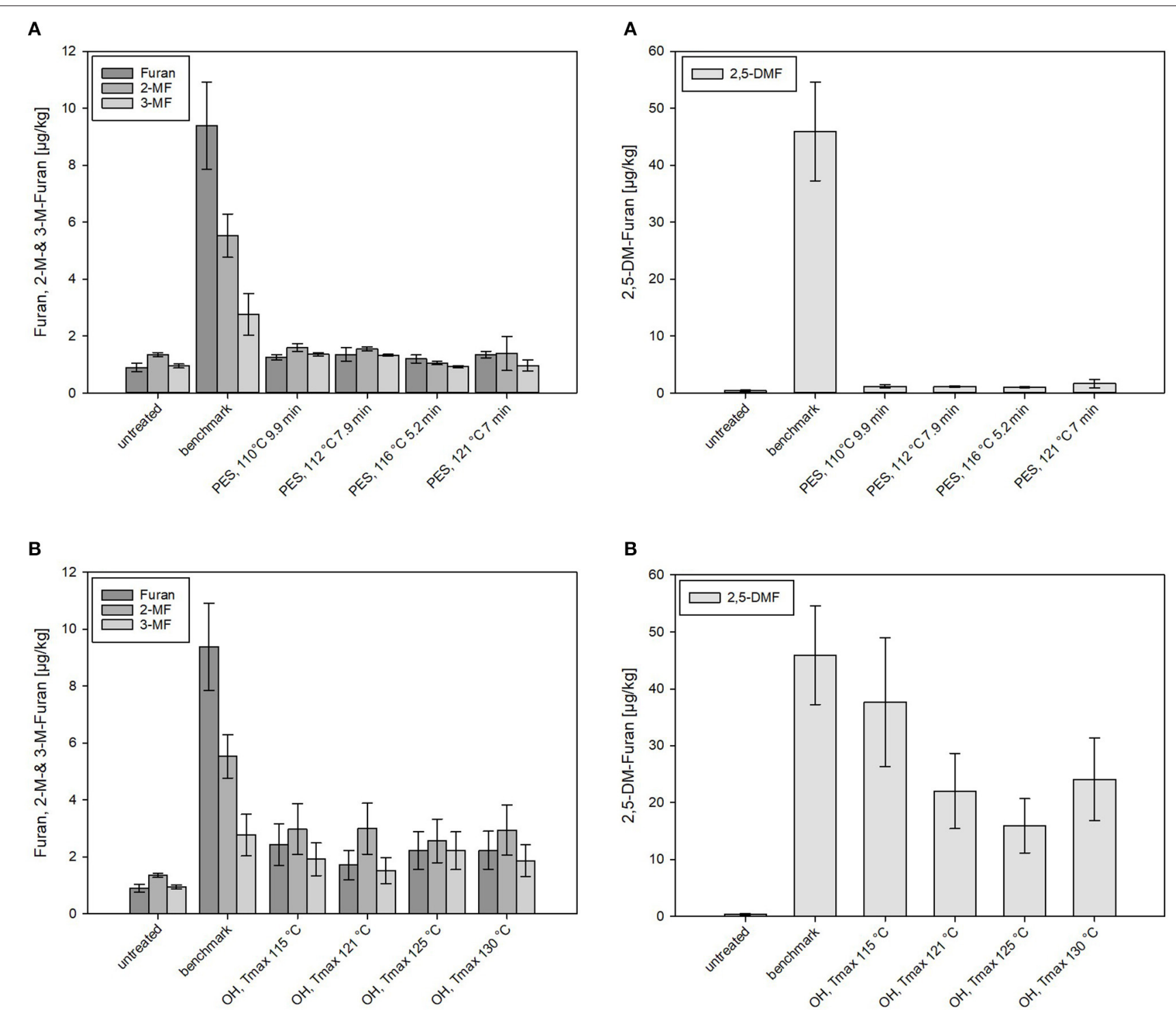

FIGURE 7 | Levels of furan and its derivates formed in chicken rice puree (CRP) after (A) pressure-enhanced sterilization (PES) and (B) ohmic heating (OH) treatments as well as industrial benchmark sterilization in comparison to the untreated sample. $\mathrm{OH}$ and benchmark samples were sterilized at a target $\mathrm{F}_{0}=7$ min. $\mathrm{OH}$ samples were treated by different maximum temperatures $\left(115,121,125\right.$, and $\left.130^{\circ} \mathrm{C}\right)$. For $130^{\circ} \mathrm{C} \mathrm{OH}$ treatment, the $\mathrm{F}_{0}$ value was $13.2 \mathrm{~min}$. Error bars represent $95 \%$ confidence interval.

in the recipe did not lead to a particularly high furan formation as compared to the carrot-oil model purees. This is not in accordance with results of other authors who reported enhanced furan formations in starch-based gels by the addition of proteins (70). On the other hand, the results are in accordance with data reported by Hradecky et al. (30), who found lower levels of furan in vegetable purees containing chicken meat $\left(13-14 \mu \mathrm{g} / \mathrm{kg}\right.$ for $\mathrm{F}_{0}$ $=8-16 \mathrm{~min})$ than in samples without chicken $(29-32 \mu \mathrm{g} / \mathrm{kg}$ for $\left.\mathrm{F}_{0}=11-20 \mathrm{~min}\right)$.

To be able to compare the different sterilization technologies (PES, OH, and benchmark retort) in relation to the applied thermal load, furan levels formed in treated CRP were plotted against the determined $\mathrm{C}$ values for all treatments, illustrating graphically the mitigation potential of the different technologies. In CRP, the furan levels were overall relatively low. The levels of furan in PES- and $\mathrm{OH}$-sterilized samples (independent from the attained $\mathrm{C}$ value) were below $2.5 \mu \mathrm{g} / \mathrm{kg}$. The furan level in the industrial benchmark samples was only mediocre although significantly higher than all PES and $\mathrm{OH}$ samples, including the one $\mathrm{OH}$ sample with a higher $\mathrm{C}$ value (Figure 8A).

Overall, relatively high amounts of 2,5-DMF were formed in all thermal ( $\mathrm{OH}$ and benchmark) samples but not in PESsterilized samples (Figures 7, 8B). 2,5-DMF is a recently found new derivate of furan and not much is known about its occurrence and formation (3). According to the results, applied pressure had an influence on the formation pathway, since by 
A

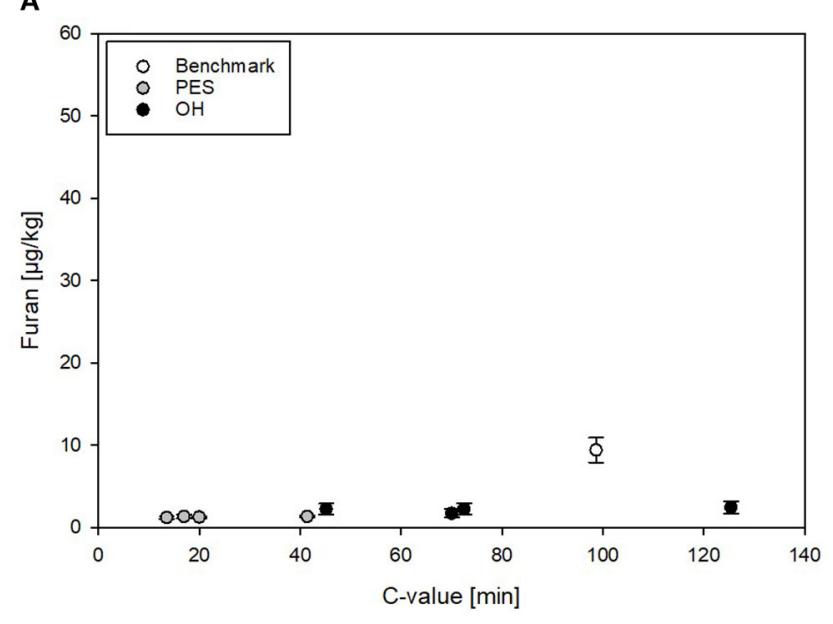

B

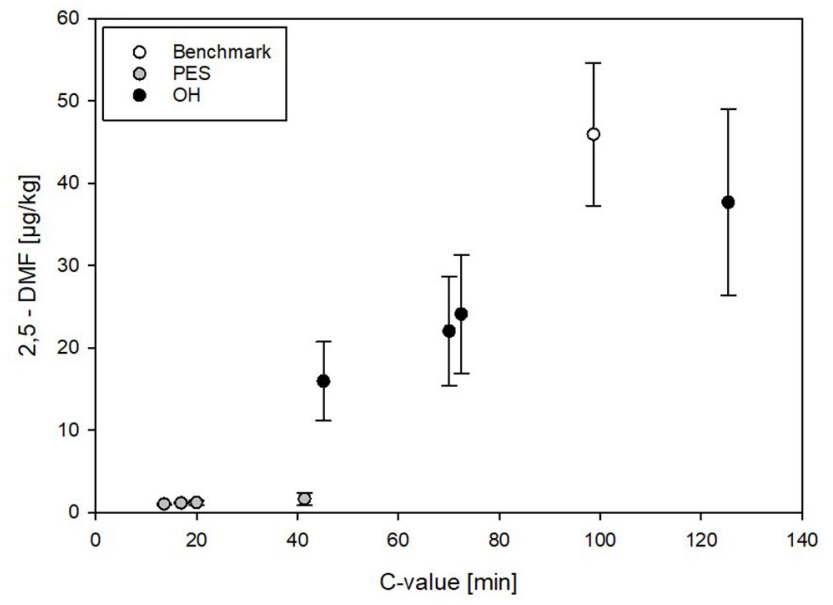

FIGURE 8 | (A) Furan and (B) 2,5-DMF levels in chicken rice puree (CRP) plotted against the C value resulting from pressure-enhanced sterilization (PES), ohmic heating $(\mathrm{OH})$, and industrial benchmark treatments. Error bars represent $95 \%$ confidence interval.

addition of pressure, lower amounts were formed in comparison to the amounts formed in the thermal processes. The highest level of 2,5-DMF was found in the industrial benchmark puree $\left(45.9 \mu \mathrm{g} / \mathrm{kg}\right.$ ). An impact of the $\mathrm{T}_{\max }$ was observed in the samples sterilized by $\mathrm{OH}$ : the minimum amount of 2,5-DMF having been formed with a $\mathrm{T}_{\max }$ of $125^{\circ} \mathrm{C}(15.9 \mu \mathrm{g} / \mathrm{kg})$ and the maximum amount with a $\mathrm{T}_{\max }$ of $115^{\circ} \mathrm{C}(37.7 \mu \mathrm{g} / \mathrm{kg})$. These observations were in accordance with the $\mathrm{C}$ values determined for the purees (Table 5). Interestingly, neither in the untreated CRP $(<3 \mu \mathrm{g} / \mathrm{kg})$ nor in the sterilized carrot-oil model purees $(<5 \mu \mathrm{g} / \mathrm{kg}$ at up to $\mathrm{F}_{0}=21$ ) were such high 2,5-DMF levels found.

When comparing the 2,5-DMF formation in $\mathrm{PES}, \mathrm{OH}$, and benchmark samples in relation to the $\mathrm{C}$ values, the high mitigation potential of PES can be seen (Figure 8B). Even at a $\mathrm{C}$ value comparable to the lowest $\mathrm{C}$ value reached by $\mathrm{OH}$, significantly lower 2,5-DMF levels were found. In the $\mathrm{OH}$ samples, the formation of 2,5-DMF increased with increasing $\mathrm{C}$ value, with the highest level at $\mathrm{T}_{\max }=115^{\circ} \mathrm{C}(\mathrm{C}$ value $=$ $125.4 \mathrm{~min})$. It can be clearly seen that, due to its potential to reduce the $\mathrm{C}$ value by more efficient heating, $\mathrm{OH}$ has a higher potential for mitigation of furan and its derivates than the retort process.

It can be concluded that pressure had an influence on the formation pathway of furan and its derivates. Lower amounts of furan and its derivates were formed when the parameter pressure was added than under the same conditions in the thermal process. In this case, PES offers a double benefit by reducing toxicological potential as well as by improving the microbiological safety of the food. In the future, more samples and analytes need to be tested to fully understand the influence of pressure on the reaction pathway. $\mathrm{OH}$ offers the advantage of more rapid and uniform heating and, therefore, the potential to reduce thermal damage during sterilization treatments. The analyses showed that the applied analytical method was able to detect even low amounts of furan.
In general, knowledge of methylfuran formation in food is very scarce and not well understood (3). For 2-MF, a pathway based on a Maillard-type reaction, including reducing sugars and specific amino acids, was proposed in model food systems (55, 61). 2-MF was reported to be formed primarily when amino acids were present. The formation was stated to be based on aldol reactions of Strecker aldehydes of certain amino acids, with lactaldehyde (from threonine) being one of the key intermediate products (55). Furthermore, also unsaturated aldehydes originating from oxidation of unsaturated fatty acids, like linolenic acid, might be relevant precursors for the corresponding methylfurans (3). However, because there is still no data to be found dealing specifically with the formation of 2,5-DMF, further research is necessary.

Very little data are available concerning the presence of 2,5DMF in food products. Shen et al. (71) analyzed various food products for the occurrence of furans and methylfurans including 2,5-DMF. They found levels of $0.5-41 \mu \mathrm{g} / \mathrm{kg}$ of $2,5-\mathrm{DMF}$ in various soy sauce, vinegar, and coffee products, but the levels were always lower than furan and 2-MF. The highest amount of 2,5-DMF was found in a milk sample with $88.8 \mu \mathrm{g} / \mathrm{kg}$. However, in fruit- and vegetable-based baby food purees, no 2,5-DMF was detected. Therefore, compared to other vegetablebased baby food preparations, the levels of 2,5-DMF found in the present study (up to $45.9 \mu \mathrm{g} / \mathrm{kg}$ ) in a carrot-based puree were surprisingly high.

In commercially available flour- or cereal-based baby food meals, Habibi et al. (72) found comparably high levels of 2,5-DMF (69.4-230.3 $\mu \mathrm{g} / \mathrm{kg}$ ). Furthermore, in five out of six samples, 2,5-DMF was the dominant process contaminant, with higher levels than furan and 2-MF. Thus, according to scientific literature, cereal- and milk-related preparations were found to be more prone to 2,5-DMF formation. The CRP investigated in the current study contained a cereal source (10\% rice), which might have contributed to the 2,5-DMF formation. However, 
more research is necessary to investigate the formation pathway and to identify the precursors of the furan derivate.

\section{Impact of the Sterilization Treatments on the Carotenoid Content}

Carotenoids are a typical quality parameter often affected by thermal treatments, and therefore, were analyzed in the CRP before and after the treatments. The results of the carotenoid content of all CRP samples can be found in Figure 9.

For the untreated sample, an average total carotenoid content (including $\alpha$ - and $\beta$-carotene) of $5.2 \pm 0.4 \mathrm{mg} / 100 \mathrm{~g}$ was determined. The recipe contained $40 \%$ carrots, and if one uses the average amount of carotenoids found in carrots with 12.3 $\mathrm{mg} / 100 \mathrm{~g}$ [based on AUSNAT (73)] to roughly estimate the amount of carotenoids in the sample, $\sim 4.9 \mathrm{mg} / 100 \mathrm{~g}$ should be found in the untreated sample. This is in accord with the amount of carotenoids found in the untreated sample. In general, for different PES treatments, not only minor losses with $\sim 7 \%$ but also increases of the carotenoid content up to $\sim 9 \%$ can be observed. The industrial benchmark process leads to a loss of $31 \%$ of the original carotenoid content.

By $\mathrm{OH}$, no better retention of the analyzed total carotenoids ( $\alpha$ - and $\beta$-carotenoids) compared to the industrial benchmark samples was observed. All sterilization treatments resulted in a reduction in the total carotenoid levels in the purees (Figure 9A). In the purees sterilized by $\mathrm{OH}$, carotenoid levels ranged between 4 and $5 \mathrm{mg} / 100 \mathrm{~g}$; this corresponded to a loss of $50-60 \%$ based on the original carotenoid content.

Literature data on the influence of PES on carotenoids are scarce. Sánchez et al. (74) investigated the carotenoid content in six different vegetables (carrot, red pepper, tomato, broccoli, spinach, and green pepper) and their changes under PES conditions (625 MPa, $\left.5 \mathrm{~min}, 117^{\circ} \mathrm{C}\right)$ and found similar results directly after the treatment. The raw carrots contained in a total of $\alpha$ - and $\beta$-carotene an amount of $13.86 \mathrm{mg} / 100 \mathrm{~g}$. This is similar to what was found in the Australian food database (73). The results indicated that after preheating, the carotenoids increased by $15 \%$. Sánchez et al. (74) mentioned that the rise could be explained by the fact that the application of pressure and/or temperature lead to a softening of the plant tissue and denaturation of proteins that could help to release carotenoids. After the PES treatment $\left(625 \mathrm{MPa}, 5 \mathrm{~min}, 117^{\circ} \mathrm{C}\right)$, they accounted loss of $\sim 7 \%$ of the initial carotenoid content. This was in accordance to loss (4-6\%) of carotenoids in the CRP, treated at 117 and $118^{\circ} \mathrm{C}$, although in this case, no comparison was performed with a thermal process, respectively. In terms of carotenoid retention directly after the treatment, PES seems to be superior to the thermal benchmark processing. Future studies should be conducted to evaluate how storage may influence the carotenoid profile for PES and for a thermal benchmark process. Here, especially for PES, packaging and its barrier properties will play an important role.

From previous literature, it is known that thermal treatments may lead to better accessibility and bioavailability of carotenoids. However, severe thermal treatments may reduce the carotenoid content in food (75). The available data on this topic is therefore contradictory. Dhuique-Mayer et al. (76) investigated the impact of different thermal treatments on the carotenoid content of sweet-potato-containing baby purees. Sterilization treatments $\left(123^{\circ} \mathrm{C}, 30 \mathrm{~min}, \mathrm{~F}_{0}=16.1 \mathrm{~min}\right)$ lead to a loss of $32 \%$ of alltrans- $\beta$-carotene in the puree. Similar results were reported for orange pepper puree after an intense heat treatment $\left(130^{\circ} \mathrm{C}, 1 \mathrm{~h}\right)$, lutein was reduced by about $90 \%$ and zeaxanthin by about $50 \%$ (77). In carrot juice, loss of 60 and $55 \%$ for $\alpha$ - and $\beta$-carotene were observed during retort sterilization $\left(121^{\circ} \mathrm{C}, 30 \mathrm{~min}\right)(78)$. Milder sterilization treatments $\left(110^{\circ} \mathrm{C}, 5 \mathrm{~min}\right)$ were reported to not significantly reduce the amount of carotenoids in carrot juice (79).

Very little data are available regarding the effect of $\mathrm{OH}$ on the carotenoid content of vegetable juices or purees. Yildiz et al. (46) investigated the $\beta$-carotene content of spinach puree during $\mathrm{OH}$ treatment up to a temperature of $90^{\circ} \mathrm{C}$. Slightly higher $\beta$ carotene concentrations were observed after $\mathrm{OH}$ treatment than by water bath heating. However, overall, only a minor impact of the two treatments on $\beta$-carotene was reported. Additionally, the voltage gradient $(10-40 \mathrm{~V} / \mathrm{cm})$ did not have a significant influence on the $\beta$-carotene concentration (46). An OH treatment and a conventional water bath heating of carrot cubes up to $97^{\circ} \mathrm{C}$ resulted in higher $\beta$-carotene concentrations than that of raw carrots. The results were linked to textural degradation and, therefore, a better extractability of the carrot tissue. No distinct impact of the $\mathrm{OH}$ treatment compared with that of the conventional thermal treatment was identified (80). On the other hand, Mannozzi et al. (81) demonstrated that during $\mathrm{OH}$ of carrot juice at temperatures above $40^{\circ} \mathrm{C}$, the amount of carotenoids decreased due to the presence of oxygen.

When comparing the two volumetric sterilization technologies, only PES was able to improve the carotenoid retention as compared to that of the industrial benchmark process. By OH, carotenoid levels were slightly lower than those of the benchmark sample. This was unexpected, as the more rapid and uniform $\mathrm{OH}$ treatments also led to lower final $\mathrm{C}$ values than those of the industrial benchmark sample. However, it cannot be ruled out that the sample handling during the $\mathrm{OH}$ treatments might have influenced the carotenoid degradation, although the sample was cooled inside the treatment chamber and quickly transferred into the sample container and immediately frozen. The additional exposure to oxygen during the transfer from the treatment chamber to the sample container might have affected the carotenoid content.

\section{Color}

Color is an important quality characteristic of fruit- and vegetable-based products and a major factor affecting sensory perception and consumer acceptance of foods. It can be assumed that the color of the food for PES as well as for $\mathrm{OH}$ is closer to the untreated product since shorter processing time and/or, in general, a lower thermal load is applied in comparison to traditional retort conditions. This results in the preservation of heat-labile bioactive compounds (e.g., chlorophyll, carotenoids, anthocyanins, etc.) responsible for the color of fruits and vegetables. 

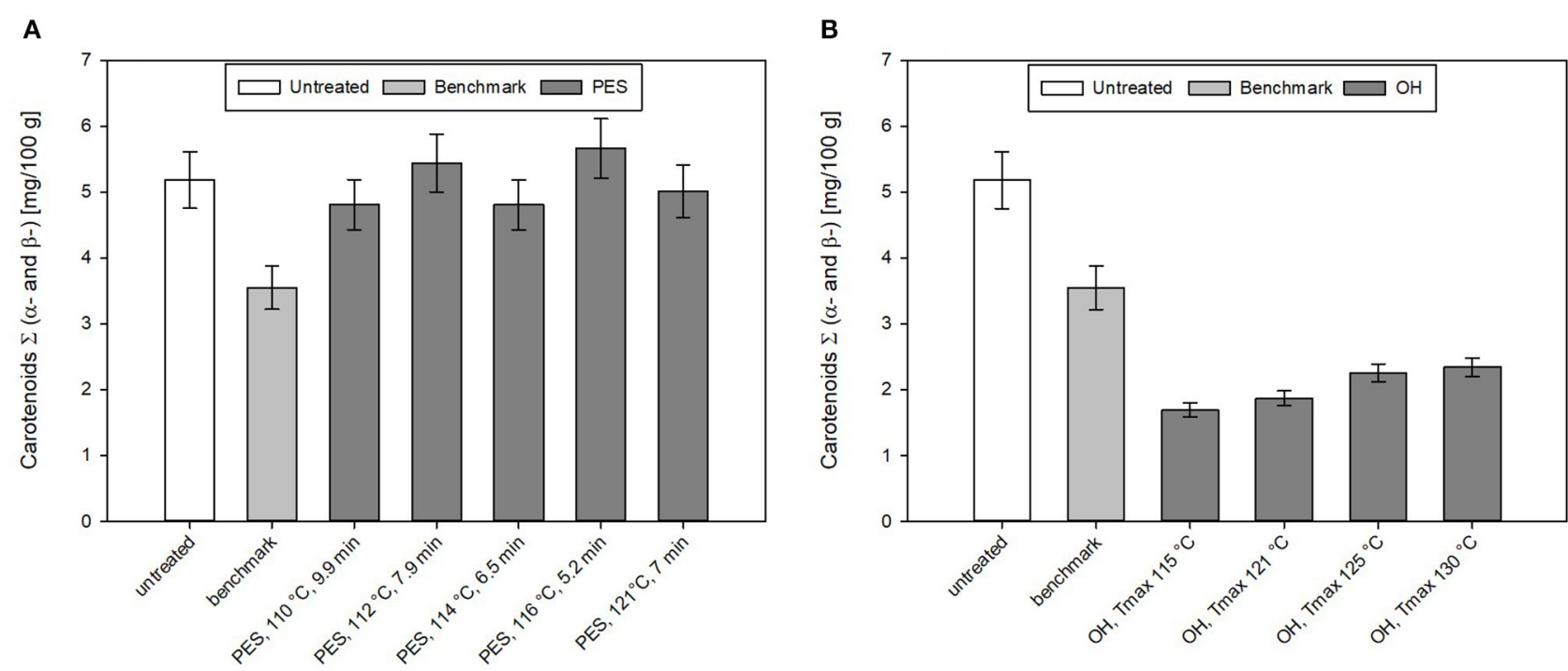

FIGURE 9 | Carotenoid content of chicken rice puree (CRP) after the (A) pressure-enhanced sterilization (PES) and (B) ohmic heating (OH) treatment as well as industrial benchmark sterilization in comparison to the untreated sample. $\mathrm{OH}$ and benchmark samples were sterilized at $\mathrm{F}_{0}=7$. OH samples were treated by different maximum temperatures $\left(115,121,125\right.$, and $\left.130^{\circ} \mathrm{C}\right)$. For $130^{\circ} \mathrm{C} \mathrm{OH}$ treatment, the $\mathrm{F}_{0}$ value was 13.2 min. Error bars represent $95 \%$ confidence interval.

The changes in color $\left(\mathrm{L}^{*}, \mathrm{a}^{*}, \mathrm{~b}^{*}\right.$ values, and $\left.\Delta \mathrm{E}\right)$ of the PES- and $\mathrm{OH}$-treated samples are shown in Figures 10A,B, respectively. All the tested parameters for $\mathrm{OH}$ equal to $\mathrm{F}_{0}=7 \mathrm{~min}$ (except $\mathrm{OH} \mathrm{T}_{\max }=130^{\circ} \mathrm{C}$ equaled $\mathrm{F}_{0}=13.2 \mathrm{~min}$ ) and for PES theoretically lead to the inactivation of $12 \log _{10}$. The $\mathrm{L}^{*}, \mathrm{a}^{*}$, and $b^{*}$ measurements were conducted with the same system to have a better overall comparison of the tested technologies.

If one looks at the changes in the single values of $\mathrm{L}^{*}, \mathrm{a}^{*}$, and $\mathrm{b}^{*}$, changes between the untreated and the industrial benchmark process occurred especially for the $\mathrm{L}^{*}$ and $\mathrm{a}^{*}$ value, whereas $\mathrm{b}^{*}$ remained almost the same (Figure 10). After the benchmark treatment, the sample was slightly darker (lower $L^{*}$ value) and lost some of the redness (lower $a^{*}$ value). The PES samples mainly showed changes in the $\mathrm{a}^{*}$ (lower) and the $\mathrm{b}^{*}$ value (lower), meaning a loss in red and yellow, respectively, orange. The $\Delta \mathrm{E}$ of the industrial benchmark process was the highest with $\sim 10.18$ in comparison to that of the PES-treated samples, which ranged between 3.76 and 6.00. Therefore, PES had a smaller impact on the color in comparison to the industrial benchmark, which, in this case, can be attributed to the lower thermal load applied ( $\mathrm{C}$ value, Table 5). The selected treatment conditions under pressure lead to a theoretical $12 \log _{10}$ inactivation and only affected the color of the final product to a minor degree. The calculated C values for these PES treatments ranged from 13 to $19 \mathrm{~min}$ and lead to similar color changes in terms of $\Delta \mathrm{E}$. Even the sample with the highest thermal load $\left(121^{\circ} \mathrm{C}, 7 \mathrm{~min}, 600 \mathrm{MPa}\right)$ and with a $\mathrm{C}$ value of $41 \mathrm{~min}$ had a similar $\Delta \mathrm{E}$ as the other samples. This may indicate that a maximum color change for this product, based on the $\Delta \mathrm{E}$, was reached within the tested temperaturetime-pressure domain. The literature concerning the influence of PES on color is scarce. There is one publication from Al-Ghamdi et al. (82), which looked at the influence of pressure-assisted thermal sterilization (PATS, with initial temperature $98^{\circ} \mathrm{C}$, mean temperature over $5 \mathrm{~min}$ of treatment at $600 \mathrm{MPa} \sim 107.5^{\circ} \mathrm{C}$ ) on nutrients and quality of pumpkin, butternut squash, pea, beetroot, and purple potato purees. Since $121.1^{\circ} \mathrm{C}$ was not attained during the process portrayed in the publication, and due to the given temperature profile, their process should rather be understood as a pressure-enhanced process. All treatments induced color changes and led to $\Delta \mathrm{E}$ values in the range from 3 to 14, contrary to the untreated samples. Especially, the greenish and purplish color of peas and the purple potato puree changed extremely under PATS. Pumpkin (orange), butternut squash (yellow), and beetroot (dark red) were not affected as much. A comparison with a thermal benchmark process was not part of the study and would have been helpful to evaluate and classify the degree of change induced by the high-pressure high-temperature process.

The $\mathrm{OH}$ treatment also significantly changed the color of the untreated puree (Figure 10B). In general, a shift from orange in the untreated samples to yellow in the sterilized samples was observed. Determined $\Delta \mathrm{E}$ values of the $\mathrm{OH}$ treatments were in a similar range, between 8.80 and 10.14 . Therefore, the $\mathrm{OH}$ samples had only slightly lower $\Delta \mathrm{E}$ values than the industrial benchmark samples. However, differences between the benchmark sample and the $\mathrm{OH}$ samples can be identified when looking closely at the $\mathrm{L}^{*}, \mathrm{a}^{*}$, and $\mathrm{b}^{*}$ values and the photos. The industrial benchmark sample was slightly darker (lower $\mathrm{L}^{*}$ value) than were the $\mathrm{OH}$ samples, and the yellowness was slightly lower (lower $b^{*}$ value). Only a slight impact of the varying $\mathrm{T}_{\max }$ values could be observed within the $\mathrm{OH}$ samples, the highest $\mathrm{T}_{\max }\left(130^{\circ} \mathrm{C}\right)$ possessing the highest $\Delta \mathrm{E}$ value (10.14). The $\mathrm{C}$ values of the $\mathrm{OH}$ treatment did not directly affect the color retention. The difference between the $\mathrm{OH}$ treatments and the benchmark sample might be due 

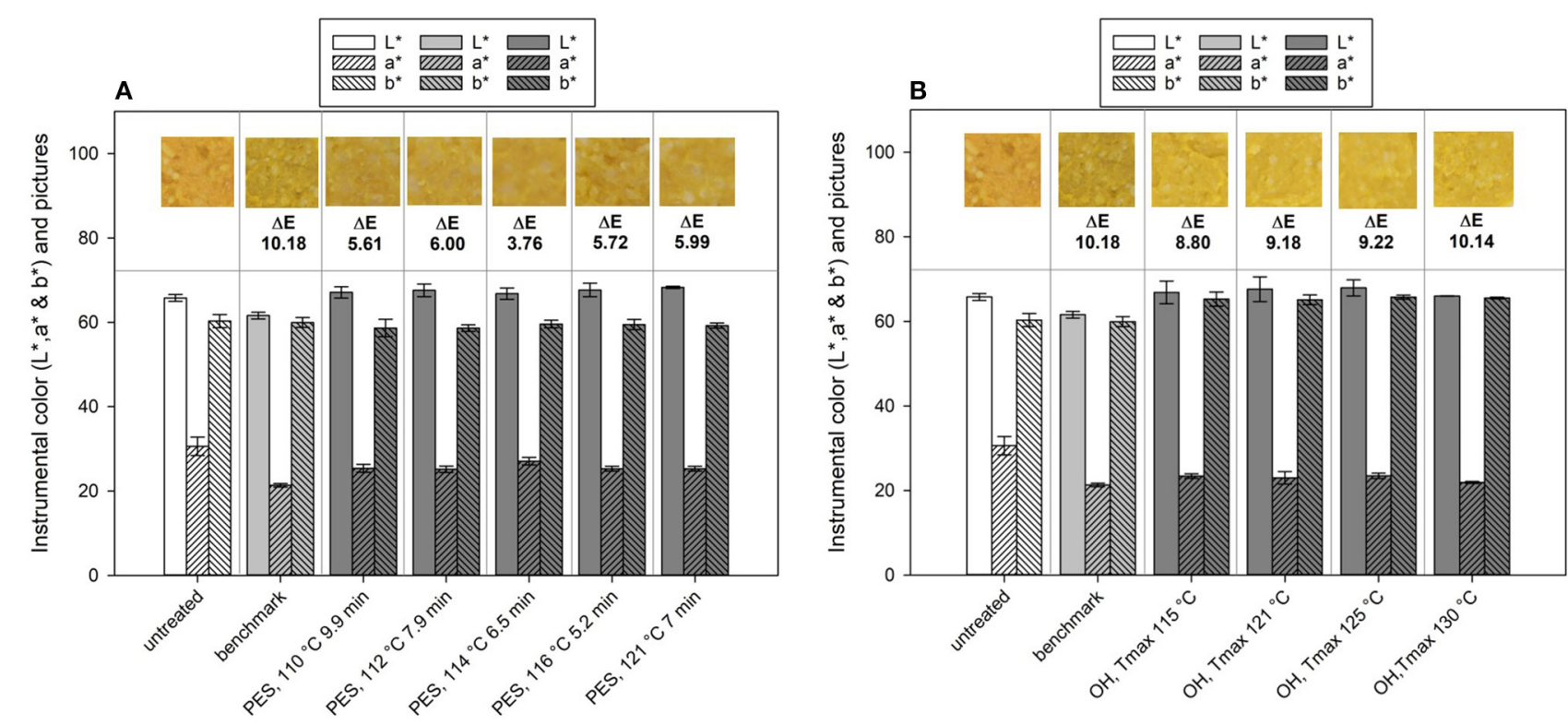

FIGURE 10 | Lab color values and calculated $\triangle E$ values of chicken rice puree (CRP) before and after processing and their representative pictures of the (A) pressure-enhanced sterilization (PES) and $(\mathbf{B})$ ohmic heating $(\mathrm{OH})$ treated samples as well as thermal benchmark sample.

to the overprocessing of the outer areas in the glass jar during the industrial retort sterilization (see Figure 4), leading to even higher $\mathrm{C}$ values in those areas.

For carrot juice, a shift from orange to yellow was reported under intense thermal treatments (78). This is in accordance with the observations made in this study, as carrots were the main component responsible for the color in the puree.

A few authors have studied the impact of $\mathrm{OH}$ treatments on color retention of fruit and vegetable purees. Yildiz et al. (46) reported good color retention of spinach purees for waterbath-heated and ohmically heated samples up to $90^{\circ} \mathrm{C}$. However, the authors also observed a slightly higher deviation from the untreated samples and a higher browning effect with $\mathrm{OH}$. In contrast to those results, an enhanced color retention by $\mathrm{OH}$ blanching compared to water bath blanching in peach puree was observed. By a more rapid and more uniform heating, the targeted enzyme inactivation could be reached more rapidly, and therefore, the color retention could be improved (47).

While comparing the two innovative technologies, $\mathrm{OH}$ had a greater influence on color change than PES and had a similar $\Delta \mathrm{E}$ as the thermal retorting. Interestingly, the changes induced by the technologies differed slightly, whereas for $\mathrm{OH}$, the $\mathrm{a}^{*}$ value was reduced and the $b^{*}$ value increased. For PES, both $a^{*}$ and $b^{*}$ value decreased. No changes were observed for either technology on the $\mathrm{L}^{*}$ value. Nevertheless, the color change for $\mathrm{OH}$ and PES is inclined toward a brighter color, as the brownish darker color corresponded to the industrial benchmark process in comparison to the untreated sample. This could be attributed to the fact that the degree of nonenzymatic browning reaction is lower for both $\mathrm{OH}$ and PES due to less cooking damage as a result of volumetric heating and shorter processing time.

\section{Texture}

To the best knowledge of the authors, no comparison has been conducted to date of the influence of three different technologies, including two emerging technologies and the conventional retorting on the textural behavior, based on a textural profile analyses of a selected food.

The texture profile analyses (TPAs) were carried out as already described under Texture. Based on the results of the TPA, a principle component analysis (PCA) was performed to find possible clusters in the textural behavior of the foods, depending on their treatment. Further, all data were normalized (put into relation to the untreated sample) prior to applying the PCA. The results of the PCA based on the results obtained by TPA from the PES, OH, and the industrial benchmark can be found in Figure 11. PC 1 contained the majority (80\%) of the information and can be used as an orientation for interpreting the results.

Clusters occurred for PES-treated, $\mathrm{OH}$-treated, untreated, and sterilized benchmark samples. The main attributes contributing to the clustering were firmness and stickiness of the treated product. The PES-treated samples increased in firmness and stickiness in correlation to the treatment temperature in comparison to the untreated sample from 50 to $100 \%$, respectively, 33-80\%. Whereas the $\mathrm{OH}$-treated samples had a similar increase in firmness (247-260\%) as the benchmark process $(255 \%)$, depending on the treatment, some variations occurred, e.g., the $\mathrm{OH}$ sample treated at $\mathrm{T}_{\max }=130^{\circ} \mathrm{C}(\mathrm{C}$ value of $72 \mathrm{~min}$, right-hand corner) showed a severe increase of $452 \%$ in firmness. The stickiness was $\sim 60 \%$ higher in comparison to the industrial benchmark process, but only minor changes occurred in the different parameter settings. Overall, in terms of change 


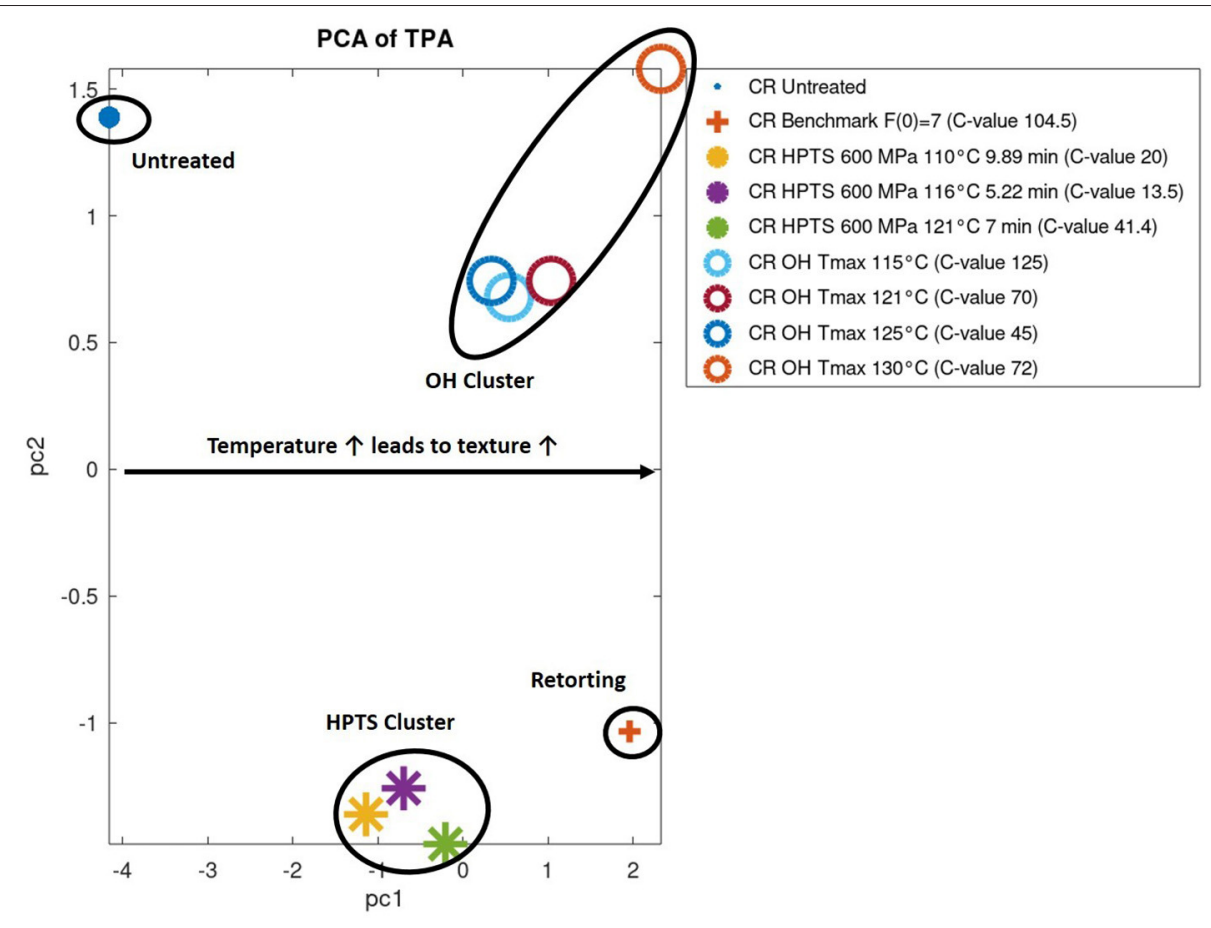

FIGURE 11 | Principle component analysis (PCA) of textural profile analysis (TPA) results of chicken rice puree (CRP) samples sterilized by pressure-enhanced sterilization (PES), ohmic heating $(\mathrm{OH})$, and benchmark retort and the untreated sample.

in texture, compared with the untreated (but precooked) sample, the PES samples are closer in value to the untreated sample as are the ohmically or the benchmark samples.

This was probably the effect of a lower thermal load applied to the product by $\mathrm{OH}$ and $\mathrm{PES}$, which, at least for some samples, is indicated by the $\mathrm{C}$ value. Otherwise, the final target temperature also seems to be important. Therefore, the gelling and texturing effect is not as pronounced as for the industrial benchmark. Nevertheless, a tendency concerning the textural fingerprint of different technologies could be shown for the first time for these emerging technologies in comparison to the benchmark retorting and an untreated reference sample. More research and data need to be evaluated to fully understand the influence of the different technologies on texture.

\section{CONCLUSION}

The present study shows that the two emerging technologies $\mathrm{OH}$ and PES are promising sterilization technologies for vegetable purees. The thermal load applied to the product, of both technologies, could be reduced compared to the conventional retort treatment, without neglecting food safety and quality. Compared to the conventional retort, lower $\mathrm{C}$ values could be reached by $\mathrm{OH}$ due to a more rapid and uniform heating of the puree samples. Even lower $\mathrm{C}$ values resulted from the PES treatments due to the synergistic inactivation effect of temperature and high pressure and the possibility to reduce processing temperature. This resulted in a better retention of color, bioactive compounds such as carotenoids, and texture, as well as a reduced formation of food processing contaminants in samples processed by the innovative sterilization technologies. Particularly, a significant reduction in the formation of both furan and its derivates could be observed, compared to the retorted samples. In the sterilized CRP samples, 2,5-DMF was found to be the dominant process contaminant, displaying higher values than furan, 2-MF, and 3-MF. High levels of 2,5-DMF were formed in thermally (industrial benchmark retort and $\mathrm{OH}$ ) sterilized CRP samples but not in PES-treated purees. Hence, PES was identified to be the most promising technology for the mitigation of the formation of furan and its derivates.

To lower the thermal impact, the best processing conditions for ohmically heated CRP were found for higher maximum temperatures, in this case $125^{\circ} \mathrm{C}$. For PES, $600 \mathrm{MPa}, 116^{\circ} \mathrm{C}$ held for $5.22 \mathrm{~min}$ was found to be the most promising parameter in terms of all quality and safety parameters tested. Additionally, trials with the selected process parameters (Table 5) were done with $200 \mathrm{~g}$ of CRP to evaluate the scalability of the PES treatment. Similar results for the physiochemical characteristics and formation of FPCs were observed compared to the small-scale trials. Results were, however, not included in the manuscript due to confidentiality issues. Further research is needed to validate these findings, which should include storage tests and sensorial evaluations. Overall, these results will help to understand the potential of the tested emerging technologies, leading to improvements in practical implementation. 


\section{DATA AVAILABILITY STATEMENT}

The original contributions presented in the study are included in the article/Supplementary Material, further inquiries can be directed to the corresponding author/s.

\section{AUTHOR CONTRIBUTIONS}

All authors listed have made a substantial, direct and intellectual contribution to the work, and approved it for publication.

\section{FUNDING}

We acknowledge the financial support of the German Federal Ministry of Economics and Energy (BMWi) (CORNET AIF 207 EN). This work was partly supported by the Austrian Research Promotion Agency (FFG Project No. 859077, volTECH). This project was supported by the BOKU Core Facility Food \&

\section{REFERENCES}

1. Matser A, Krebbers B, van den Berg R, Bartels P. Advantages of high pressure sterilization on quality of food products. Trends Food Sci Technol. (2004) 15:79-85. doi: 10.1016/j.tifs.2003.08.005

2. Stadler H, Lineback DR. Process-Induced Food Toxicanst. Occurrence, Formation, Mitigation Health Risks. Hoboken, NJ: Wiley (2009). doi: $10.1002 / 9780470430101$

3. EFSA. (2017). Risks for public health related to the presence of furan and methylfurans in food. EFSA J. 15:e05005 doi: 10.2903/j.efsa.2017.5005

4. Wuytack E, Boven S, Michiels C. Comparative study of pressure-induced germination of bacillus subtilis spores at low and high pressures. Appl Environ Microbiol. (1998) 64:3220-4. doi: 10.1128/AEM.64.9.3220-3224.1998

5. Ahn J, Balasubramaniam VM. Physiological responses of bacillus amyloliquefaciens spores to high pressure. I Microbiol Biotechnol. (2006) 17:524-9.

6. Wimalaratne S, Farid M. Pressure assisted thermal sterilization. Food Bioprod Process. (2008) 86:312-6. doi: 10.1016/j.fbp.2007.08.001

7. Mathys A, Reineke K, Heinz V, Knorr D. High pressure thermal sterilization - development and application of temperature controlled spore inactivation studies. High Press Res. (2009) 29:3-7. doi: 10.1080/08957950802526469

8. Reineke K, Doehner I, Schlumbach K, Baier D, Mathys A, Knorr D. The different pathways of spore germination and inactivation in dependence of pressure and temperature. Innov Food Sci Emerg Technol. (2012) 13:31-41. doi: 10.1016/j.ifset.2011.09.006

9. Sevenich R, Mathys A. Continuous versus discontinuous ultra-highpressure systems for food sterilization with focus on ultra-high-pressure homogenization and high-pressure thermal sterilization: a review. Compr Rev Food Sci Food Saf. (2018) 17:646-62. doi: 10.1111/1541-4337.12348

10. Knoerzer K, Juliano P, Gladman S, Fryer PJ. A computational model for temperature and sterility distributions in a pilot-scale high-pressure hightemperature process. AICHE J. (2007) 61:857-66. doi: 10.1002/aic.11301

11. Sommerville J. (2009). The Effects of Pressure-Assisted Thermal Processing on the Quality Attributes of Black Beans.

12. Institute of Food Saftey and Health Illinois. NCFST Receives Regulatory Acceptance of Novel Food Sterilization Process. (2009). Available online at: https://labs.wsu.edu/tang/2009/02/26/ncfst-receives-regulatoryacceptance- of-novel-food-sterilization-process/

13. Institute of Food Saftey and Health Illinois. IFSH Receives FDA Acceptance of Pressure Enhanced Sterilization Process for Commercial Production of Multi- Component Shelf-Stable Foods. (2015). Available online at: https:// www.food-safety.com/articles/2681-ifsh-receives-fda-acceptance-ofpressure-enhanced-sterilization-process-for-commercial-productionof-multicomponent-shelf-stable-foods
Bio Processing. Part of the equipment used in this study was financed by EQ-BOKU VIBT GmbH and belongs to the Center for Preservation and Aseptic Processing.

\section{ACKNOWLEDGMENTS}

The authors would like to thank Elisabeth Högg for establishing and setting up the TPA-method, helping us to conduct the trials, and her assistance to evaluate and analyze the data. Further, we thank Mary Violet Berger for proofreading this article.

\section{SUPPLEMENTARY MATERIAL}

The Supplementary Material for this article can be found online at: https://www.frontiersin.org/articles/10.3389/fnut.2021. 643837/full\#supplementary-material

14. Juliano P, Barbosa-Canovas G. Food sterilization by combining high pressure and thermal energy. In: Gutiérrez-López GF, BarbosaCánovas GV, Welti-Chanes J, Parada-Arias E, editors. Food Engineering: Integrated Approaches. New York City, NY: Springer (2005). p. 9-46. doi: 10.1007/978-0-387-75430-7_2

15. Knoerzer K, Buckow R, Versteeg C. Adiabatic compression heating coefficients for high pressure processing - A study of some insulating polymer materials. J Food Eng. (2010) 98:110-9. doi: 10.1016/j.jfoodeng.2009.12.016

16. De Alwis AAP, Fryer PJ. The use of direct resistance heating in the food industry. J Food Eng. (1990) 11:3-27. doi: 10.1016/0260-8774(90)90036-8

17. Sastry SK, Palaniappan S. Mathematical modeling experimental studies on ohmic heating of liquid-particle mixtures in a static heater. J Food Process Eng. (1992) 15:241-61. doi: 10.1111/j.1745-4530.1992.tb00155.x

18. Ghnimi S, Flach-Malaspina N, Dresch M, Delaplace G, Maingonnat JF. Design and performance evaluation of an ohmic heating unit for thermal processing of highly viscous liquids. Chem Eng Res Des. (2008) 86:626-32. doi: 10.1016/j.cherd.2008.02.005

19. Ruan R, Ye X, Chen P, Doona CJ, Taub I. Ohmic heating. In: Richardson P, editor. Thermal Technologies in Food Processing Woodhead Publishing Series in Food Science, Technology Nutrition. Woodhead Publishing (2001). p. 241-265. doi: 10.1533/9781855736610.3.241

20. Leizerson S, Shimoni E. Stability and sensory shelf life of orange juice pasteurized by continuous ohmic heating. J Agric Food Chem. (2005) 53:40128. doi: 10.1021/jf047857q

21. Baysal AH, Icier F. Inactivation kinetics of alicyclobacillus acidoterrestris spores in orange juice by ohmic heating: effects of voltage gradient and temperature on inactivation. J Food Prot. (2010) 73:299-304. doi: 10.4315/0362-028X-73.2.299

22. IARC. Dry cleaning: Some chlorinated solvents and other industrial chemicals. IARC Monogr Eval Carcinog Risks Hum.(1995) 63:33-475.

23. Ramirez R, Saraiva J, Pérez Lamela C, Torres JA. Reaction kinetics analysis of chemical changes in pressure-assisted thermal processing. Food Eng Rev. (2009) 1:16-30. doi: 10.1007/s12393-009-9002-8

24. Escobedo-Avellaneda Z, Pateiro Moure M, Chotyakul N, Torres J, WeltiChanes J, Lamela C. Benefits and limitations of food processing by high pressure technologies: effects on functional compounds and nonbiotic contaminants. J Food. (2011) 9:616959. doi: 10.1080/19476337.2011.6 16959

25. Bravo KS, Ramírez R, Durst R, Escobedo-Avellaneda ZJ, Welti-Chanes J, Sanz PD, et al. Formation risk of toxic other unwanted compounds in pressure-assisted thermally processed foods. J Food Sci. (2012) 77:R1-10. doi: 10.1111/j.1750-3841.2011.02451.x

26. Sevenich R, Bark F, Crews C, Anderson W, Pye C, Riddellova K, et al. Effect of high pressure thermal sterilization on the formation of food 
processing contaminants. Innov Food Sci Emerg Technol. (2013) 20:42-50. doi: 10.1016/j.ifset.2013.07.006

27. Sevenich R, Kleinstueck E, Crews C, Anderson W, Pye C, Riddellova K, et al. High-pressure thermal sterilization: food safety and food quality of baby food puree. J Food Sci. (2014) 79:M230-7. doi: 10.1111/1750-3841.12345

28. Kessler H-G. Food Bio Process Engineering: Dairy Technology. Munich: Verlag A. Kessler (2002).

29. Mesias M, Wagner M, George S, Morales FJ. Impact of conventional sterilization and ohmic heating on the amino acid profile in vegetable baby foods. Innov Food Sci Emerg Technol. (2016) 34:24-8. doi: 10.1016/j.ifset.2015.12.031

30. Hradecky J, Kludska E, Belkova B, Wagner M, Hajslova J. Ohmic heating: a promising technology to reduce furan formation in sterilized vegetable and vegetable/meat baby foods. Innov Food Sci Emerg Technol. (2017) 43:1-6. doi: 10.1016/j.ifset.2017.07.018

31. Jaeger H, Roth A, Toepfl S, Holzhauser T, Engel KH, Knorr D, et al. Opinion on the use of ohmic heating for the treatment of foods. Trends Food Sci Technol. (2016) 55:84-97. doi: 10.1016/j.tifs.2016.07.007

32. Adams MR, Moss MO, McClure P. Food Microbiology. 4 edition. Cambridge: Royal Society of Chemistry (2015).

33. Somavat R, Mohamed HMH, Chung Y-K, Yousef AE, Sastry SK. Accelerated inactivation of \{Geobacillus\} stearothermophilus spores by ohmic heating. $J$ Food Eng. (2012) 108:69-76. doi: 10.1016/j.jfoodeng.2011.07.028

34. Somavat R, Mohamed HMH, Sastry SK. Inactivation kinetics of \{Bacillus\} coagulans spores under ohmic and conventional heating. LWT - Food Sci Technol. (2013) 54:194-8. doi: 10.1016/j.lwt.2013.04.004

35. Schottroff F, Pyatkovskyy T, Reineke K, Setlow P, Sastry SK, Jaeger H. Mechanisms of enhanced bacterial endospore inactivation during sterilization by ohmic heating. Bioelectrochemistry. (2019) 130:107338. doi: 10.1016/j.bioelechem.2019.107338

36. Zell M, Lyng JG, Morgan DJ, Cronin DA. Minimising heat losses during batch ohmic heating of solid food. Food Bioprod Process. (2011) 89:128-34. doi: 10.1016/j.fbp.2010.04.003

37. Tucker G, Featherstone S. Essentials of Thermal Processing. (2010). doi: $10.1002 / 9781444328622$

38. Holdsworth D, Simpson R. eds. Sterilization, pasteurization and cooking criteria. In: Thermal Processing of Packaged Foods Food Engineering Series. Boston, MA: Springer (2007). p. 123-41. doi: 10.1007/978-0-387-72250-4_4

39. Sharma G, Bala R. Digital Color Imaging Handbook. Boca Rotten, FL: CRC Press (2017)

40. Shim SM, Lim SY. Texture properties and radical scavenging ability of porridge products based on beans, grains, and nuts. J Korean Soc Appl Biol Chem. (2013) 56:77-82. doi: 10.1007/s13765-012-2219-x

41. Forstova V, Belkova B, Riddellova K, Vaclavik L, Prihoda J, Hajslova J. Acrylamide formation in traditional Czech leavened wheat-rye breads and wheat rolls. Food Control. (2014) 38:221-6. doi: 10.1016/j.foodcont.2013.10.022

42. Moravcova E, Vaclavik L, Lacina O, Hrbek V, Riddellova K, Hajslova J. Novel approaches to analysis of 3-chloropropane-1,2-diol esters in vegetable oils. Anal Bioanal Chem. (2012) 402:2871-83. doi: 10.1007/s00216-0125732-1

43. Bhave A, Schulzova V, Chmelarova H, Mrnka L, Hajslova J. Assessment of rosehips based on the content of their biologically active compounds. J Food Drug Anal. (2017) 25:681-90. doi: 10.1016/j.jfda.2016. 12.019

44. Tucker G. (2014). Fruits and \{Vegetables\}. Ohmic Heat. Food Process.

45. Kaur R, Gul K, Singh AK. Nutritional impact of ohmic heating on fruits and vegetables-\{A\} review. Cogent Food Agric. (2016) 2:1159000. doi: 10.1080/23311932.2016.1159000

46. Yildiz H, Icier F, Baysal T. Changes in $\beta$-carotene, chlorophyll color of spinach puree during ohmic heating. J Food Process Eng. (2009) 33:763-73. doi: 10.1111/j.1745-4530.2008.00303.x

47. Icier F, Yildiz H, Baysal T. Peroxidase inactivation and colour changes during ohmic blanching of pea puree. J Food Eng. (2006) 74:424-9. doi: 10.1016/j.jfoodeng.2005.03.032

48. Schottroff F, Biebl D, Gruber M, Burghardt N, Schelling J, Gratz M, et al. Inactivation of vegetative microorganisms by ohmic heating in the kilohertz range - Evaluation of experimental setups and non-thermal effects.
Innov Food Sci Emerg Technol. (2020) 63:1-11. doi: 10.1016/j.ifset.2020. 102372

49. Sevenich R, Bark F, Kleinstueck E, Crews C, Pye C, Hradecky J, et al. The impact of high pressure thermal sterilization on the microbiological stability and formation of food processing contaminants in selected fish systems and baby food puree at pilot scale. Food Control. (2015) 50:539-47. doi: 10.1016/j.foodcont.2014.09.050

50. Olivier SA, Smith R, Bull MK, Chapman B, Knoerzer K. Apparatus for the simultaneous processing of mesophilic spores by heat-only and by high pressure and heat in a high pressure vessel to investigate synergistic spore inactivation. Innov Food Sci Emerg Technol. (2015) 27:35-40. doi: 10.1016/j.ifset.2014.12.003

51. European Commission. Commission Regulation (EU) 2017/ 2158 - of 20 November 2017 - establishing mitigation measures benchmark levels for the reduction of the presence of acrylamide in food. Off J Eur Union (2017) 21:2444. Available online at: https://eur-lex.europa.eu/eli/reg/2017/2158/oj

52. EFSA. Call for Continuous Collection of Chemical Contaminants Occurrence Data in Food and Feed. (2018). Available online at: https://www.efsa.europa. eu/en/consultations/call/190410

53. Becalski A, Hayward S, Krakalovich T, Pelletier L, Roscoe V, Vavasour E. Development of an analytical method and survey of foods for furan, 2-methylfuran and 3-methylfuran with estimated exposure. Food Addit Contam - Part A Chem Anal Control Expo Risk Assess. (2010) 27:764-75. doi: 10.1080/19440040903473332

54. Maga JA, Katz I. Furans in foods. C R C Crit Rev Food Sci Nutr. (1979) 11:355-400. doi: 10.1080/10408397909527268

55. Limacher A, Kerler J, Conde-Petit B, Blank I. Formation of furan and methylfuran from ascorbic acid in model systems and food. Food Addit Contam. (2007) 24:122-35. doi: 10.1080/02652030701393112

56. Fromberg A, Sisse F, Granby K. Furan in heated processed foods products including home cooked food products and ready-toeat products. Czech J Food Sci. (2014) 32:443-8. doi: 10.17221/341/2013-CJFS

57. Sharma KD, Karki S, Thakur NS, Attri S. Chemical composition, functional properties and processing of carrot-A review. J Food Sci Technol. (2012) 49:22-32. doi: 10.1007/s13197-011-0310-7

58. Belitz HD, Grosch W, Schieberle P. Food chemistry. (2009). Springer Berlin Heidelberg.

59. Studer A, Blank I, Stadler RH. Thermal processing contaminants in foodstuffs and potential strategies of control. Czech J Food Sci. (2004) 22:1-88. doi: 10.17221/10600-CJFS

60. Hasnip S, Crews C, Castle L. Some factors affecting the formation of furan in heated foods. Food Addit Contam. (2006) 23:219-27. doi: 10.1080/02652030500539766

61. Märk J, Pollien P, Lindinger C, Blank I, Märk T. Quantitation of furan and methylfuran formed in different precursor systems by proton transfer reaction mass spectrometry. J Agric Food Chem. (2006) 54:2786-93. doi: $10.1021 /$ jf052937v

62. Vranová J, Ciesarová Z. Furan in food - a review. Czech J Food Sci. (2009) 27:1-10. doi: 10.17221/2843-CJFS

63. Crews C. Fatty Acid Esters of Chloropropanols and Glycidol in Foods - Analysis and Exposure. (2012). Available online at: https://onlinelibrary.wiley.com/toc/ $14389312 / 113 / 3$

64. Sevenich R, Rauh C, Knorr D. A scientific and interdisciplinary approach for high pressure processing as a future toolbox for safe and high quality products: a review. Innov Food Sci Emerg Technol. (2016) 38:65-75. doi: 10.1016/j.ifset.2016.09.013

65. Kettlitz B, Scholz G, Theurillat V, Cselovszky J, Buck NRO, Hagan S, et al. Furan and methylfurans in foods: an update on occurrence, mitigation, and risk assessment. Compr Rev Food Sci Food Saf. (2019) 18:738-52. doi: $10.1111 / 1541-4337.12433$

66. Nie SP, Huang JG, Hu JL, Zhang YN, Wang S, Li C, et al. Effect of $\mathrm{pH}$, temperature and heating time on the formation of furan in sugar-glycine model systems. Food Sci Hum Wellness. (2013) 2:87-92. doi: 10.1016/j.fshw.2013.05.001

67. Adams A, Bouckaert C, Van Lancker F, De Meulenaer B, De Kimpe N. Amino acid catalysis of 2-alkylfuran formation from lipid oxidationderived $\alpha, \beta$-unsaturated aldehydes. J Agric Food Chem. (2011) 59:11058-62. doi: $10.1021 /$ jf $202448 \mathrm{v}$ 
68. Palmers S, Grauwet T, Kebede BT, Hendrickx ME, Loey A. Reduction of furan formation by high-pressure high-temperature treatment of individual vegetable purées. Food Bioprocess Technol. (2014). doi: $10.1007 /$ s11947-014-1300-3

69. Hutschenreuther S, Kalb N, Kuslys M, Weber F. Range of Aseptically Produced Infant Foods Having Low Concentrations of Undesired by-Products and Methods for Making the Same. (2009). Available online at: https:// patentscope.wipo.int/search/en/detail.jsf?docId=WO2009030488\&recNum= 213\&docAn=EP2008007263\&queryString $=$ ALL: $($ gooseberry) $\& \operatorname{maxRec}=948$

70. Owczarek-Fendor A, De Meulenaer B, Scholl G, Adams A, Van Lancker F, Eppe G, et al. Furan formation in starch-based model systems containing carbohydrates in combination with proteins, ascorbic acid and lipids. Food Chem. (2012) 133:816-21. doi: 10.1016/j.foodchem.2012.01.098

71. Shen M, Liu Q, Jia H, Jiang Y, Nie S, Xie J, et al. Simultaneous determination of furan and 2-alkylfurans in heat-processed foods by automated static headspace gas chromatography-mass spectrometry. LWT - Food Sci Technol. (2016) 72:44-54. doi: 10.1016/j.lwt.2016.04.030

72. Habibi H, Mohammadi A, Hoseini H, Mohammadi M, Azadniya E. Headspace liquid-phase microextraction followed by gas chromatographymass spectrometry for determination of furanic compounds in baby foods and method optimization using response surface methodology. Food Anal Methods. (2013) 6:1056-64. doi: 10.1007/s12161-012-9510-7

73. Australian Food Database. Food Nutrient Database. (2020). p. 1-2. Available online at: https://link.springer.com/article/10.1007\%2Fs12161-012-9510-7

74. Sánchez C, Baranda AB, De Marañón IM. The effect of High Pressure and High Temperature processing on carotenoids and chlorophylls content in some vegetables. Food Chem. (2014) 163:37-45. doi: 10.1016/j.foodchem.2014.04.041

75. Maiani G, Castón MJP, Catasta G, Toti E, Cambrodón IG, Bysted A, et al. Carotenoids: actual knowledge on food sources, intakes, stability and bioavailability and their protective role in humans. Mol Nutr Food Res. (2009) 53 (Suppl. 2):S194-218. doi: 10.1002/mnfr.2008 00053

76. Dhuique-Mayer C, Servent A, Messan C, Achir N, Dornier M, Mendoza Y. Bioaccessibility of Biofortified Sweet Potato Carotenoids in Baby
Food: Impact of Manufacturing Process. Front Nutr. (2018) 5:98. doi: 10.3389/fnut.2018.00098

77. Mayer-Miebach E, Behsnilian D. Lutein- and Zeaxanthin (bio)availability due to thermal processing of orange pepper. Jahresbericht. (2006).

78. Chen BH, Peng HY, Chen HE. Changes of carotenoids, color, and vitamin a contents during processing of carrot juice. J Agric Food Chem. (1995) 43:1912-8. doi: 10.1021/jf00055a029

79. Liao H, Sun Y, Ni Y, Liao X, Hu X, Wu J, et al. The effect of enzymatic mash treatment, pressing, centrifugation, homogenization, deaeration, sterilization and storage on carrot juice. J Food Process Eng. (2007) 30:421-35. doi: 10.1111/j.1745-4530.2007.00118.x

80. Tola YB, Ramaswamy HS. Effect of novel processing techniques on texture softening and $\beta$-carotene content of thermally processed carrots. Food Bioprocess Technol. (2014) 7:2986-99. doi: 10.1007/s11947-014-1286-X

81. Mannozzi C, Fauster T, Haas K, Tylewicz U, Romani S, Dalla Rosa M, et al. Role of thermal and electric field effects during the pre-treatment of fruit and vegetable mash by pulsed electric fields $(\mathrm{PEF})$ and Ohmic heating $(\mathrm{OH})$. Innov Food Sci Emerg Technol. (2018) 48:131-7. doi: 10.1016/j.ifset.2018.06.004

82. Al-Ghamdi S, Sonar CR, Patel J, Albahr Z, Sablani SS. High pressure-assisted thermal sterilization of low-acid fruit and vegetable purees: microbial safety, nutrient, quality, and packaging evaluation. Food Control. (2020) 114:107233. doi: 10.1016/j.foodcont.2020.107233

Conflict of Interest: The authors declare that the research was conducted in the absence of any commercial or financial relationships that could be construed as a potential conflict of interest.

Copyright (C) 2021 Gratz, Sevenich, Hoppe, Schottroff, Vlaskovic, Belkova, Chytilova, Filatova, Stupak, Hajslova, Rauh and Jaeger. This is an open-access article distributed under the terms of the Creative Commons Attribution License (CC BY). The use, distribution or reproduction in other forums is permitted, provided the original author(s) and the copyright owner(s) are credited and that the original publication in this journal is cited, in accordance with accepted academic practice. No use, distribution or reproduction is permitted which does not comply with these terms. 